\title{
History of petroleum systems in the southern part of the Broad Fourteens Basin
}

\author{
J.M. Verweij ${ }^{1}$, H.J. Simmelink ${ }^{1}$, R.T.Van Balen ${ }^{2} \&$ P. David ${ }^{1}$ \\ 1 Netherlands Institute of Applied Geoscience TNO - National Geological Survey, \\ P.O. Box 80015, 3508TA Utrecht, the Netherlands; E-mail: j.verweij@nitg.tno.nl \\ 2 Faculty of Earth and Life Sciences, Vrije Universiteit, De Boelelaan 1085, \\ $1081 \mathrm{HV}$ Amsterdam, the Netherlands
}

Manuscript received: January 2002; accepted: January 2003

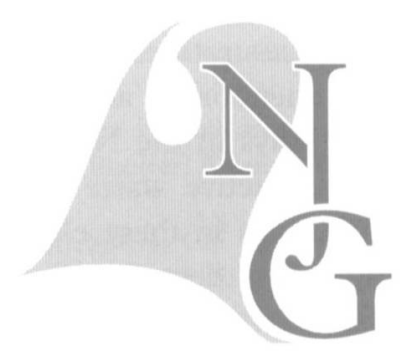

\begin{abstract}
2D Basin modelling was used to evaluate the response of source rock maturation, and of petroleum expulsion, migration, accumulation and preservation to the evolution of the southern part of the inverted Broad Fourteens Basin. Modelling results show that the temperature, maturation and petroleum generation history as well as migration characteristics of both the Jurassic oil systems and the Carboniferous gas systems vary over short distances relative to the differences in burial history of the basin. Model results indicate that no major gas accumulations are preserved in the Slochteren Formation along the cross-section at present-day. Gas accumulations are predicted in sandstone-dominated Triassic units in the southern part of the section. Present-day oil accumulations predicted in the Vlieland Sandstone Formation sealed by the Vlieland Claystone Formation (in P9 and Q1 crestal structures) are in accordance with known oil accumulations. Additional oil accumulations are predicted in the sandstone-dominated Middle Werkendam Member, and in sandstones of the Delfland Subgroup.

The modelling offers an explanation for the different geochemical compositions of the accumulated oils in the P9 and Q1 areas. Modelling implies, that the oils in the Q1 oil field were sourced by remigrated oils expelled over time, from early mature to mature source rocks of the Posidonia Shale Formation. The biodegraded and water-washed nature of the Q1 oil is explained by the concentrated topography-induced groundwater flow through the Vlieland Sandstone Formation during the Late Cretaceous inversion of the basin. The oils accumulated in the P9 area were sourced from an early mature part of the Posidonia Shale Formation and were probably not affected by water washing and biodegradation because of post-inversion charging of the reservoir.
\end{abstract}

Keywords: petroleum systems, basin modelling, Broad Fourteens Basin, North Sea Basin

\section{Introduction}

This paper presents results of a $2 \mathrm{D}$ basin modelling study along a cross section in the southern part of the Broad Fourteens Basin (Fig. 1). The modelling study was part of an integrated basin study of the Broad Fourteens Basin (Verweij et al., 2000; Verweij \& Simmelink, 2002; Verweij, 2003). The research presented here aimed to increase the understanding of and provide a time framework for petroleum generation, migration, accumulation and preservation in the basin.

The Broad Fourteens Basin, located in the Dutch part of the southern North Sea, has been extensively studied since the first successful exploration well in 1968 (Oele et al., 1981; Van Wijhe, 1987; RRI, 1984, 1985, 1988, 1990; Lee et al,. 1989; Van der Poel, 1989; Hastings et al., 1991; Roelofsen \& De Boer, 1991; Nalpas et al., 1995; Goh, 1996; Gauthier et al., 2000; Wong et al., 2001). As a consequence, there is a wide range of information and data - geological, geophysical, thermal and geochemical - available on it (both from published sources and public wells). We have used these data to obtain an a priori understanding of the past geological, hydrogeological, geother- 


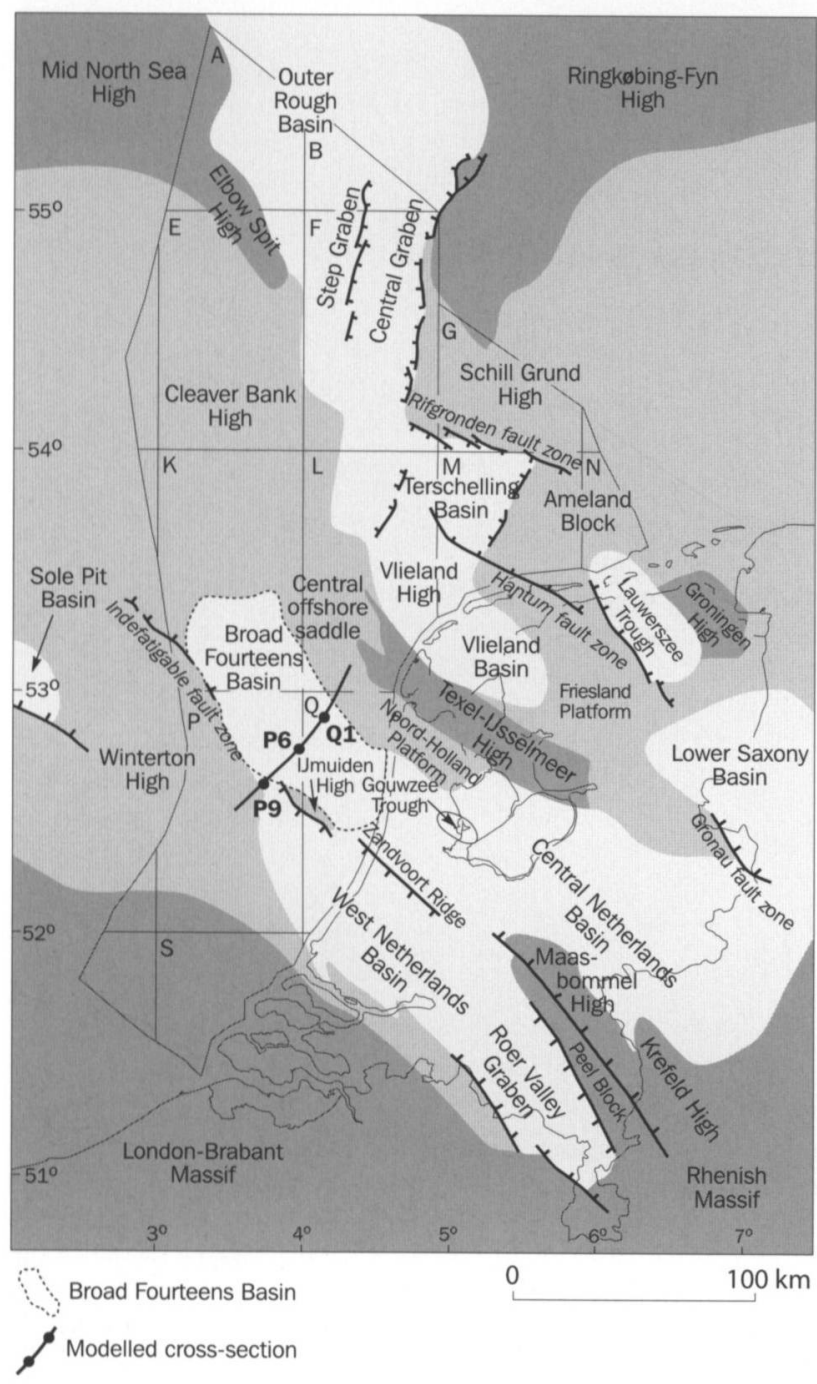

Fig. 1 Location of the Broad Fourteens Basin and the modelled cross-section

mal and petroleum-geological processes which are responsible for the present-day characteristics of the oil and gas systems of the basin, and to quantify its burial and uplift history (Verweij \& Simmelink, 2002; Verweij, 2003). This previous data analysis provided the understanding as well as the input data, boundary conditions and different scenarios required for the 2D basin modelling. The $2 \mathrm{D}$ basin modelling has been used to analyse the integrated basin evolution along the cross-section and to quantify, date and time the different processes. The cross-section traverses a Q1 and the edge of a P9 oil accumulation, but doesn't include any known commercially exploited gas accumulation (Fig. 2).

A specific focus of the modelling study was to increase the process-based understanding of the observed difference in composition of the P9 and Q1 oils and the absence of commercially exploited gas accumulations along the cross-section (where did all the gas go?). The Broad Fourteeens Basin has a similar geologic history as the nearby West Netherlands Basin (Fig. 1). Van Balen et al. (2000) studied this basin, using similar modelling techniques.

\section{Geological setting}

The Broad Fourteens Basin is a northwest-southeast trending Mesozoic basin, approximately $120 \mathrm{~km}$ long and $45 \mathrm{~km}$ wide (Fig. 1). The geological setting of the basin is treated in great detail in Verweij (2003) and references therein. The main features are summarised here.

The basin is now inverted and covered unconformably by the sedimentary fill of the Southern North Sea Basin (Cenozoic). It rests on the Southern Permian Basin, which in turn unconformably overlies an even older sedimentary basin: the Variscan foreland basin.

The present-day structural framework and Upper Carboniferous to recent sedimentary record of the Broad Fourteens area reflect a complex history of extension and inversion related to changes in the megatectonic setting of the basin. Changes in tectonic stress during the evolution of the basin include both long term gradual changes in tectonic stress regime from an active extensional stress regime (Triassic to Early Cretaceous) towards a compressional stress regime (Late Cretaceous to present-day) and pulse like changes in compressive stress during the Late Cretaceous inversion period and beyond. On the basis of the relationship between changes in tectonic setting and sedimentary history, the basin's stratigraphy was subdivided into six major tectono-stratigraphic sequences (Fig. 3).

The Variscan sequence includes the Carboniferous coal measures that are the main gas-prone source rocks in the basin. Pre- and early rift development of the basin resulted in a largely conformable sedimentary sequence (Upper Rotliegend, Zechstein and Germanic Trias Groups, and the oil-prone Aalburg and Posidonia Shale Formation of the Altena Group). During the main syn-rift phase, sedimentation of the Schieland Group was concentrated in the rapidly subsiding fault-bounded basin while erosion proceeded on adjacent uplifted highs. Post-rift thermal subsidence and associated deposition of Rijnland and Chalk Group deposits were interrupted by the Late Cretaceous inversion. During the inversion period the syn-rift sedimentary fill of the basin was uplifted and strongly eroded and the Broad Fourteens Basin formed a regional high. Syn-inversion deposition of chalk continued in adjacent areas. The Cenozoic post-inversion development of the basin was dominated by regional subsidence, interrupted by some 


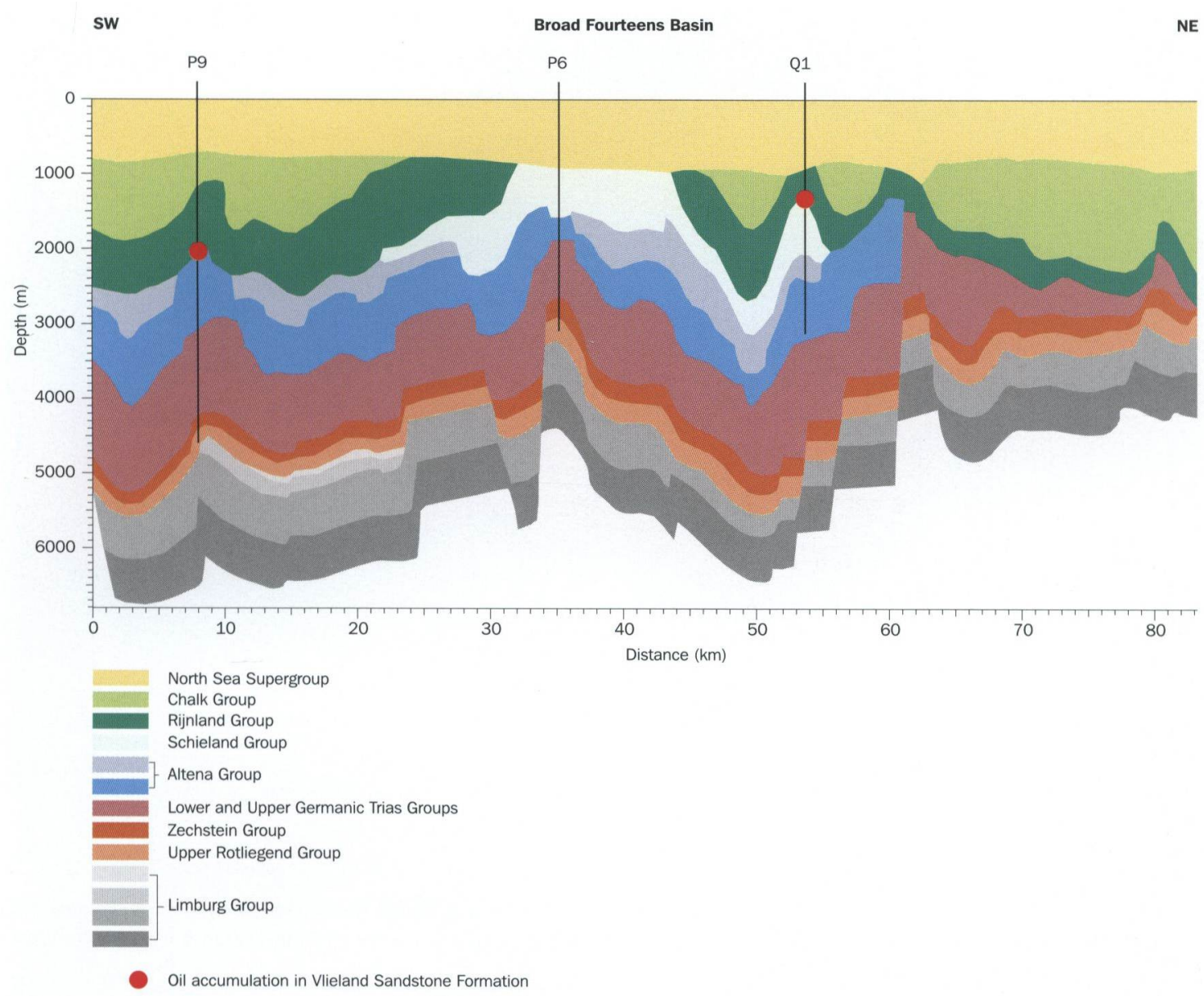

Fig. 2. Geologic framework along cross-section through the southern part of the Broad Fourteens Basin. Geologic framework is based on inhouse interpreted seismic sections SNST-83-02 and NNS-6, in combination with published cross-sections (Burgers \& Mulder, 1991). Additional information on the geometry of the Upper Rotliegend Group, Limburg Group and - in the southern parts also - the Zechstein and Germanic Trias Groups was derived from declassified well data and regional information (Van Adrichem Boogaert \& Kouwe, 1993-1997; RRI, 1988; Quirk \& Aitken, 1997 and Van Wijhe et al., 1980). Fig. 1 shows the location of the modelled cross-section.

distinct compressive phases. A major compressive phase at the Eocene-Oligocene boundary induced uplift of the basin and erosion of previously deposited marine Lower North Sea Group sediments. Subsequent marine sedimentation of the Middle North Sea Group was interrupted by the Savian phase at the end of the Oligocene. Sedimentation rates during deposition of the marine and continental Upper North Sea Group sediments started to increase during the Pliocene and remained relatively high during the Quaternary.

\section{Petroleum systems}

The first successful exploration well drilled by Mobil in the Broad Fourteens Basin encountered gas in Zechstein carbonates and Triassic sandstones in the P6 block in 1968. The first oil fields (Helm and Helder fields) were discovered by Union Oil in block Q1 in 1979 (Knaap \& Coenen, 1987). Most oil and gas fields in the basin are located along its margins.
Fig. 3 illustrates the stratigraphic position of the main source rocks and reservoir units.

\section{Gas system}

Important commercial gas accumulations are present in the Slochteren Formation and, in addition, in Zechstein Carbonate Members and in the Main Buntsandstein Subgroup of the Broad Fourteens Basin. The principal top seal of the Slochteren reservoir consists of Zechstein evaporites (e.g., Oele et al., 1981; Roos \& Smits, 1983; Frikken, 1996). The dominantly gas-prone Westphalian coal measures of the Limburg Group are considered to be the main source rock for gas in the basin (e.g. Van Wijhe et al., 1980; Oele et al., 1981; Van Wijhe, 1987; Glennie, 1998). The source rock is of kerogen type III. Well data show that the coal content of the Baarlo Formation is $1.5 \%$, the Ruurlo Formation is $4 \%$ and that of the Maurits Formation is $6 \%$, while the total organic carbon (TOC) content of the coals is at least $70 \%$, simi- 


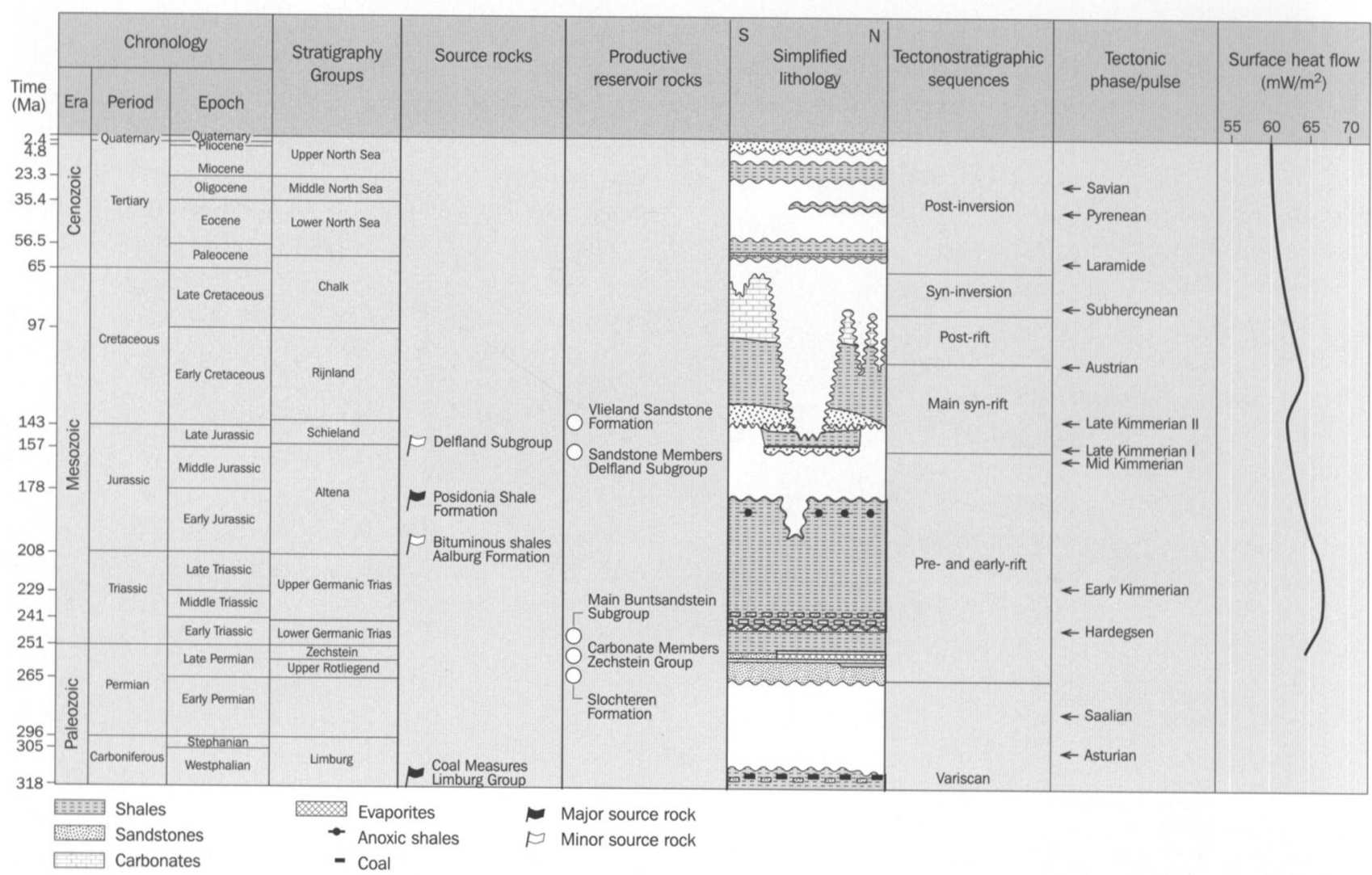

Fig. 3. Stratigraphy, lithology and history of tectonic events and surface heat flow of the Broad Fourteens Basin. Stratigraphy and lithology are representative for the southern part of the basin. The evolution of the surface heat flow is derived from in-house tectonic forward modelling of the tectonic subsidence curve of well P09-01A.

lar to the West Netherlands Basin (Van Balen et al., 2000). A second gas system based on Namurian source rocks has been proposed and modelled for the West Netherlands Basin by Van Balen et al. (2000). Such a system could also be present in the Broad Fourteens Basin, but has not been included in this modelling study.

\section{Oil system}

Commercial oil accumulations are principally found in the Vlieland Sandstone Formation, and the Delfland Subgroup. The Vlieland Claystone Formation is the top seal for oil accumulations in blocks Q1 and K18 (Roelofsen \& De Boer, 1991; De Jong \& Laker, 1992). The majority of the current faulted anticlinal traps in the Vlieland Sandstone Formation formed during the Late Cretaceous-Early Tertiary inversion (Dronkers \& Mrozek, 1991; Hastings et al., 1991; Roelofsen \& De Boer, 1991). The Helm, Helder, Hoorn and Haven fields (block Q1) of the Posidonia Shale-Lower Cretaceous oil system contain water washed and biodegraded oils (Roelofsen \& De Boer, 1991). The Posidonia Shale Formation, a kerogen type II source rock (Cornford, 1998), is considered to be the most important source rock for oil in the
Broad Fourteens Basin (Roelofsen \& De Boer, 1991; De Jong \& Laker, 1992; Goh, 1996). TOC content for the Posidonia shale is approximately $5 \%$. The bituminous shale of the Delfland Subgroup, is considered by Roelofsen \& De Boer (1991), to be a secondary source rock for oil. In addition, Cornford (1998) suggests that Lower Jurassic shales may have developed oil and gas potential in the basin.

\section{Modelling methodology}

The Temispack modelling tool was used to evaluate the response of source rock maturation, and petroleum expulsion, migration, accumulation and preservation to the evolution of the basin along the cross-section. Temispack is a finite-volume model that uses a two-D mesh to simulate the following conditions during basin evolution (Ungerer et al., 1990):

- Sedimentation, erosion and compaction. The model simulates changes in geometrical framework of the model layers based on normal porosity-depth curves defined for each lithology, and taking into account the paleogeography and the vertical displacements of the layers.

- Heat flow and temperature. The calculation of temperature history is based on a transient heat flow 
equation that uses lithology and porosity dependent thermal conductivities, heat capacities and radiogenic heat production based on lithology, and takes into account the evolution of the sediment-water interface temperatures and the evolution of basal heat flow.

- Source rock kerogen maturity and petroleum generation. The input for the maturity module includes kerogen type, total organic carbon (TOC) values and temperature history from the previous module. In this study, Temispack default kerogen types and the associated kinetic model were used. The maturity module computes the transformation ratios for each source rock type and the amount of petroleum generated. Vitrinite reflectances are computed for Type IV reference kerogen.

- Fluid flow. The history of pore pressures and groundwater flow is calculated to be the combined result of sedimentary loading and unloading, the relief of the water table and, in addition, the generation of hydrocarbons. The module requires the input of the relationships between porosity and effective stress for each lithology, as well as the permeabilities derived from the lithology-related porosities by applying the Kozeny-Carman equation, and finally, the anisotropies.

- Petroleum expulsion, migration and accumulation. The petroleum migration module links the previous modules and calculates the expulsion and migration history by using a two-phase Darcy equation. It requires additional input of relative permeability functions, petroleum density and viscosity, and capillary pressures.
The history of sedimentation, uplift and erosion was derived from backstripping of the present-day cross-section and subsequent forward modelling of the structure and lithostratigraphy. The cross-section was divided into 42 geochronologic events and 31 different lithotypes, and was divided laterally into 83 vertical columns. The Appendix gives the lithotypes and associated hydraulic and thermal parameters. Subsequently, the history of sedimentation, uplift and erosion in combination with the geothermal history along the cross-section since the Late Carboniferous was quantified and verified against present-day temperature, vitrinite reflectance and porosity data (Simmelink \& Verweij, 2000). It provided the starting conditions for the subsequent forward modelling scenarios of the groundwater and petroleum system. Evaluation of the first modelling results of different scenarios for groundwater and petroleum fluid flow in combination with our previously compiled conceptual geological and fluidgeological model led to the final selection of a model scenario to simulate the permeability history as part of the subsequent groundwater and petroleum fluid simulation (Verweij et al., 2000; Verweij \& Simmelink, 2002; Verweij, 2003). This basinmodelling scenario incorporated dynamic fault and fracture zone permeability. For this purpose four vertical fault columns were introduced into the crosssection at locations corresponding to major fault zones (in P9, P6 and Q1 areas) identified from seismic data (Fig. 4). The predefined fault zones have enhanced vertical permeabilities during the early stages of Late Jurasssic rifting and the Late Cretaceous and Tertiary inversion and uplift periods.

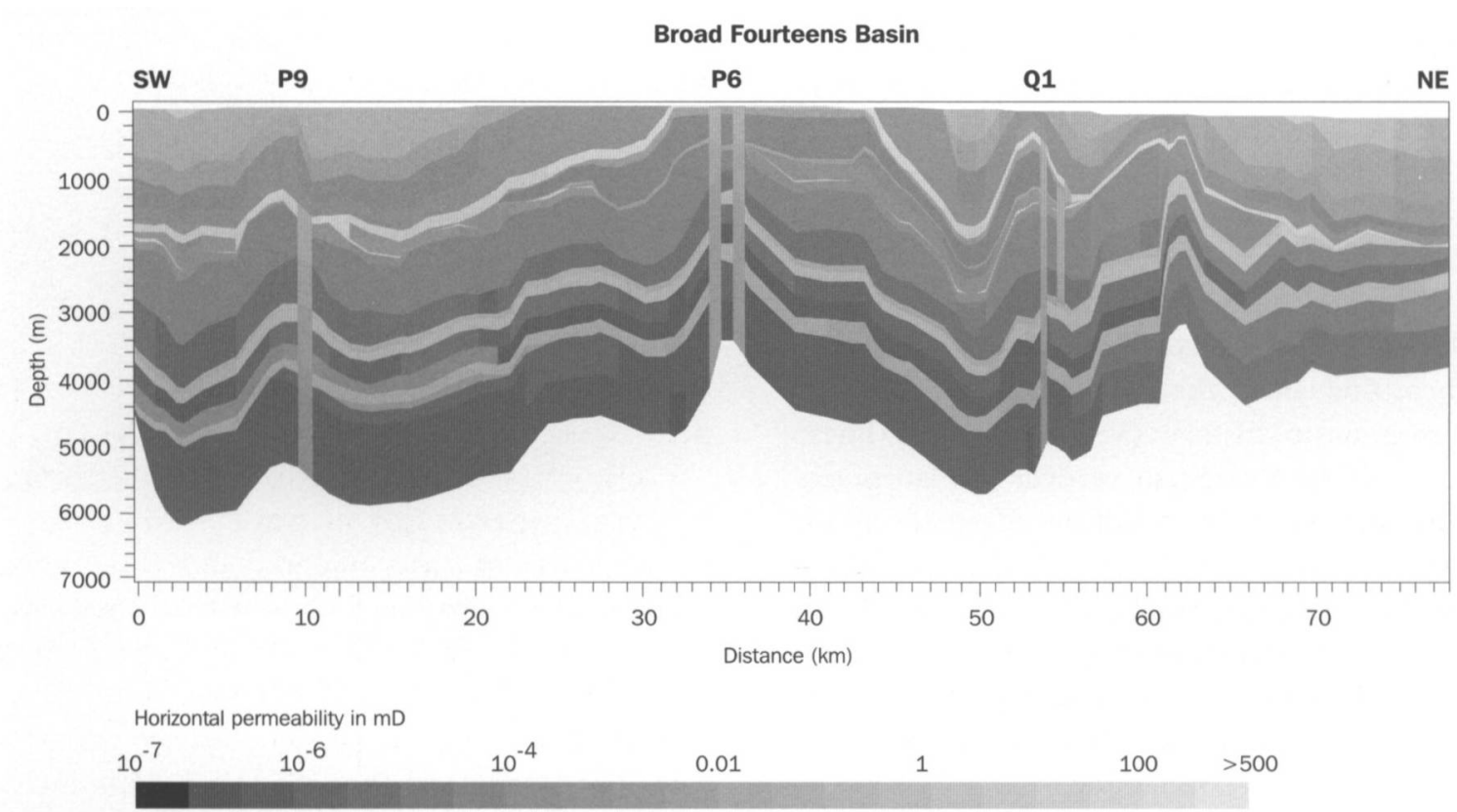

Fig. 4. Predicted distribution of horizontal permeability during the syn-inversion phase of basin evolution, including location of fault zones with dynamic permeability. 


\section{Modelling results: burial history}

The predicted burial histories of pre-inversion tectono-stratigraphic units show large differences along the cross-section (Verweij, 2003). The Variscan to early-rift tectono-stratigraphic units, including the Carboniferous and Jurassic source rock units, in the central parts of the basin reached their maximum depths of burial prior to the Late Cretaceous syn-inversion period and are presently not at their maximum depth of burial, with the possible exception of a small area at $50 \mathrm{~km}$ along the cross-section. In the southern part of the section the units are presently approximately at pre-inversion depth at the structural high corresponding to well location $\mathrm{P} 9$, and at maximum burial depth southward (0-7 km) and northward of the high $(10-20 \mathrm{~km})$. To the north of the actual basin (at $62-78 \mathrm{~km}$; northern platform) the Carboniferous and Triassic units are presently at their maximum depth of burial.

\section{Modelling results: history of temperature and heat flow}

\section{Input data and boundary conditions}

The temperature and heat flow history along the cross section were simulated assuming transient heat flow conditions and taking into account time-dependent top and bottom boundary conditions (Fig. 5), zero heat flow across lateral boundaries, radiogenic heat production in the sediments, and porosity-dependent heat conduction and heat capacities of the sediments. The bottom boundary condition was based on basal heat flow history reconstructed by forward modelling of tectonic subsidence at three locations along the section (see Van Balen et al., 2000 for a description of the modelling procedure).

\section{Predicted history of temperature and heat flow}

Thermal modelling revealed lateral and vertical variations in heat flow along the cross-section at different times during basin history (Verweij, 2003). These variations could be related to vertical displacements of the basin and the evolution of the thermal boundary conditions. For example, contrasting uplift and subsidence histories of the central part of the basin and the northern platform during the main syn-rift and the syn-inversion phase of basin evolution resulted in lateral variations in heat flow along the crosssection of approximately $8 \mathrm{~mW} / \mathrm{m}^{2}$.

The simulated temperature history of the source rocks largely followed the burial histories of these
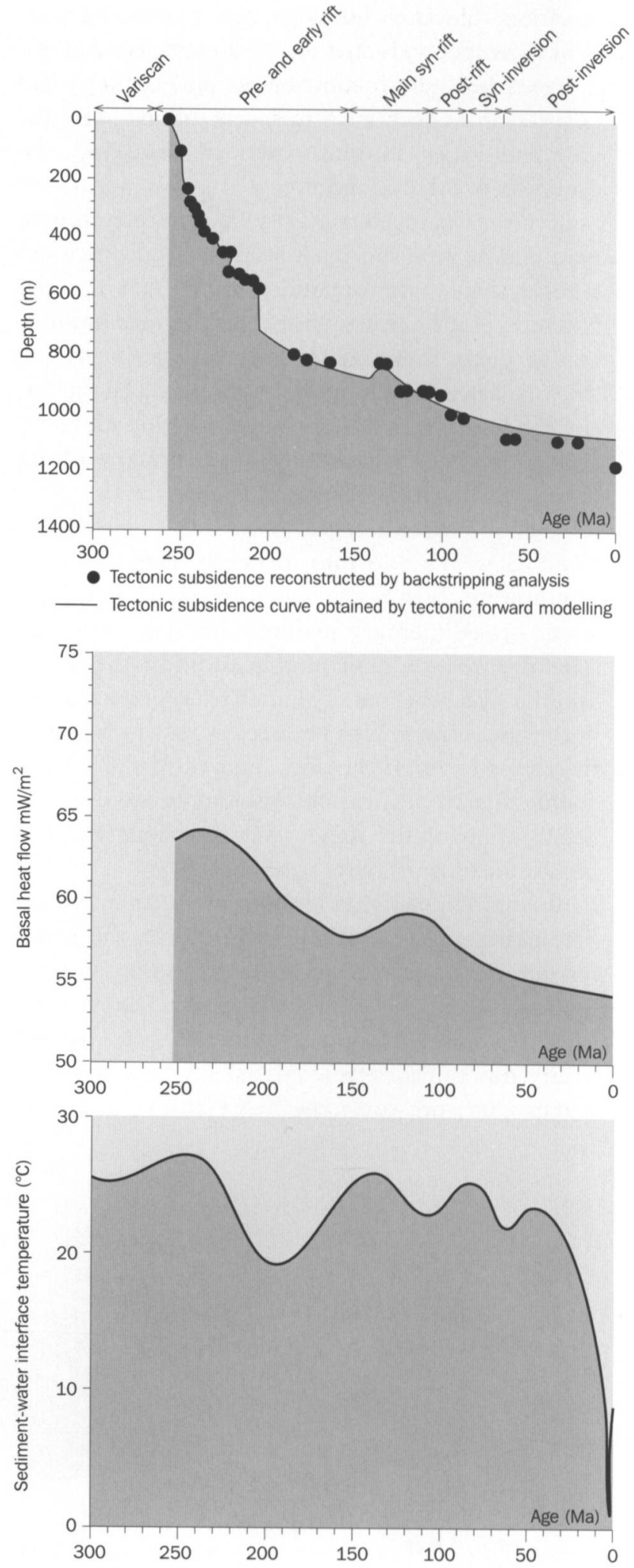

Fig. 5a. Tectonic subsidence curve for well P09-01A; b Evolution basal heat flow derived from in-house tectonic forward modelling of the tectonic subsidence curve of well P09-01A; c Evolution sediment-water interface temperatures.

rocks. The temperatures increased with increasing depth of burial, and decreased with uplift and erosion. However, during Mid to Late Tertiary times the 
temperatures decreased during burial, mainly because of changing surface thermal boundary conditions: ground surface temperatures dropped from approximately $22^{\circ} \mathrm{C}$ to $8^{\circ} \mathrm{C}$. The present-day temperatures of the Carboniferous and Jurassic source rocks along the entire cross-section are lower than the maximum temperatures experienced during burial. The source rocks in the southern part of the cross-section and in the northern platform area reached their maximum temperatures just prior to the Eocene-Oligocene uplift. In the central most inverted part of the basin the source rocks experienced maximum temperatures just before the Late Cretaceous phase of inversion. Predicted present-day temperatures are in accordance with observed temperatures (Fig. 6).

\section{Modelling results: history of maturation and pe- troleum generation}

Input data

The model includes three source rock intervals: the Carboniferous coal measures of the Limburg Group, the Jurassic Posidonia Shale Formation, and the Aalburg Formation (Appendix). The gas-prone coal measures of the Limburg Group comprise kerogen type III and include the Baarlo Formation, Ruurlo Formation, Maurits Formation and the Dinkel and Hunze Subgroups with a TOC content of $0.7 \%, 2.8 \%, 4.2 \%$ and $0.7 \%$, respectively. The oil-prone Posidonia Shale Formation is of kerogen type II with a TOC content of $5 \%$. The Aalburg Formation was taken into account as an additional kerogen type II source rock for oil with a TOC content of $1 \%$.

\section{Predicted history of maturation and petroleum generation}

The burial histories of the, gas-prone, Carboniferous source rocks show large differences along the crosssection. As a result there are very different temperature and maturation histories for the source rocks depending on their structural position (Fig. 7).

The Limburg Group source rock in the central and southern part of the cross section first entered the gas window at the end of the early-rift phase, except for the basinal area between P6 and $50 \mathrm{~km}$. Here, the gas window is reached during the main syn-rift period. Most gas was generated prior to the inversion. In the northern platform area, maximum maturity was reached in the Early Tertiary post-inversion period, initiating a first phase of gas generation in the most deeply buried rocks. The predicted amount of total gas generated during the evolution of the Broad Fourteens Basin is largest in the southern part of the cross-
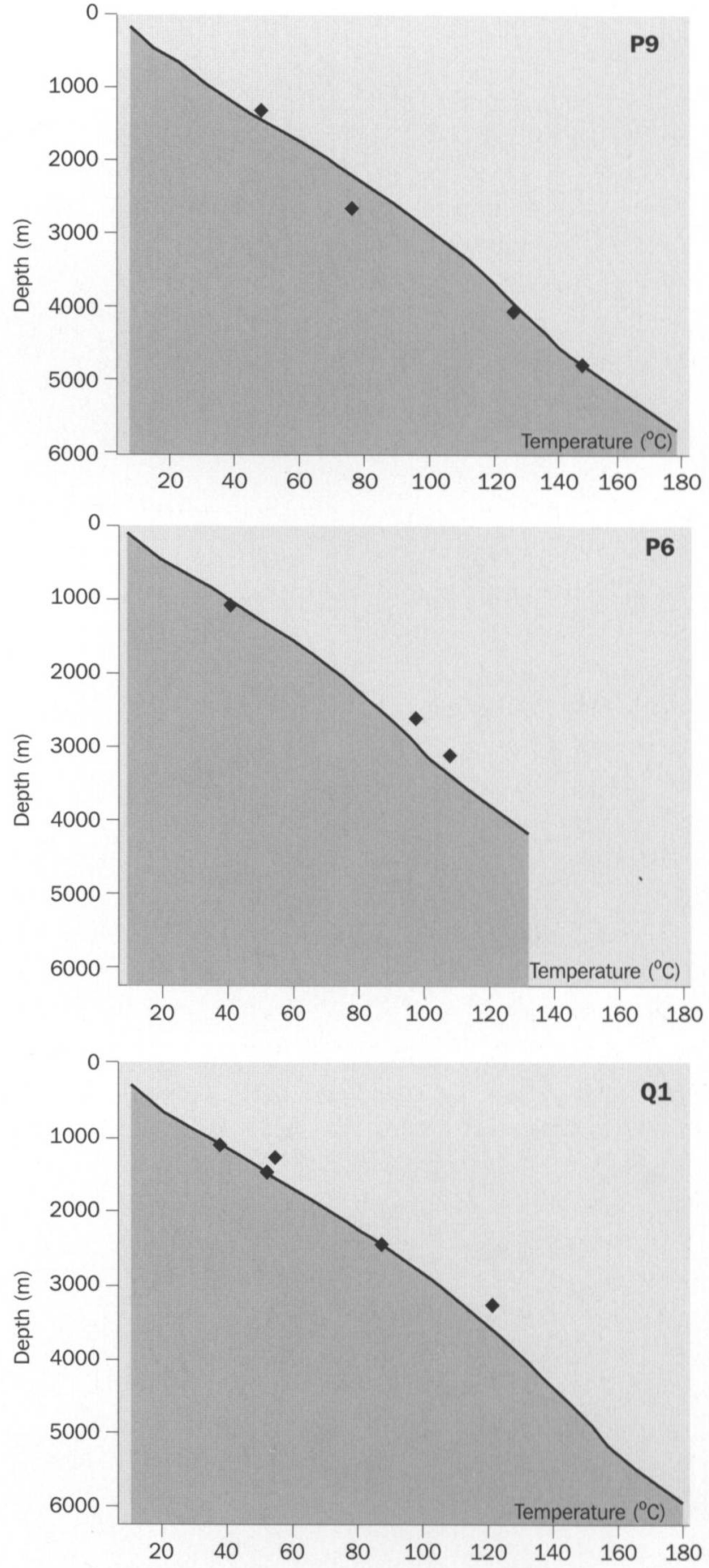

Fig. 6.Predicted temperature - depth relations at present-day and observed temperatures for wells P09-01A, P06-02 and Q01-03.

section (Fig. 8), where the Maurits Formation (with the highest assigned coal content) survived the EarlyPermian erosion.

Major production of $\mathrm{CO}_{2}$ from the Carboniferous source rocks probably occurred just before the onset of catagenesis (corresponding to the $0.8-0.95 \%$ vitrinite reflectance interval; Crépieux et al., 1998). Maximum generation of $\mathrm{CO}_{2}$ in the basinal area - estimated from the modelled history of vitrinite reflectance took place during early rift and early syn-rift times, 

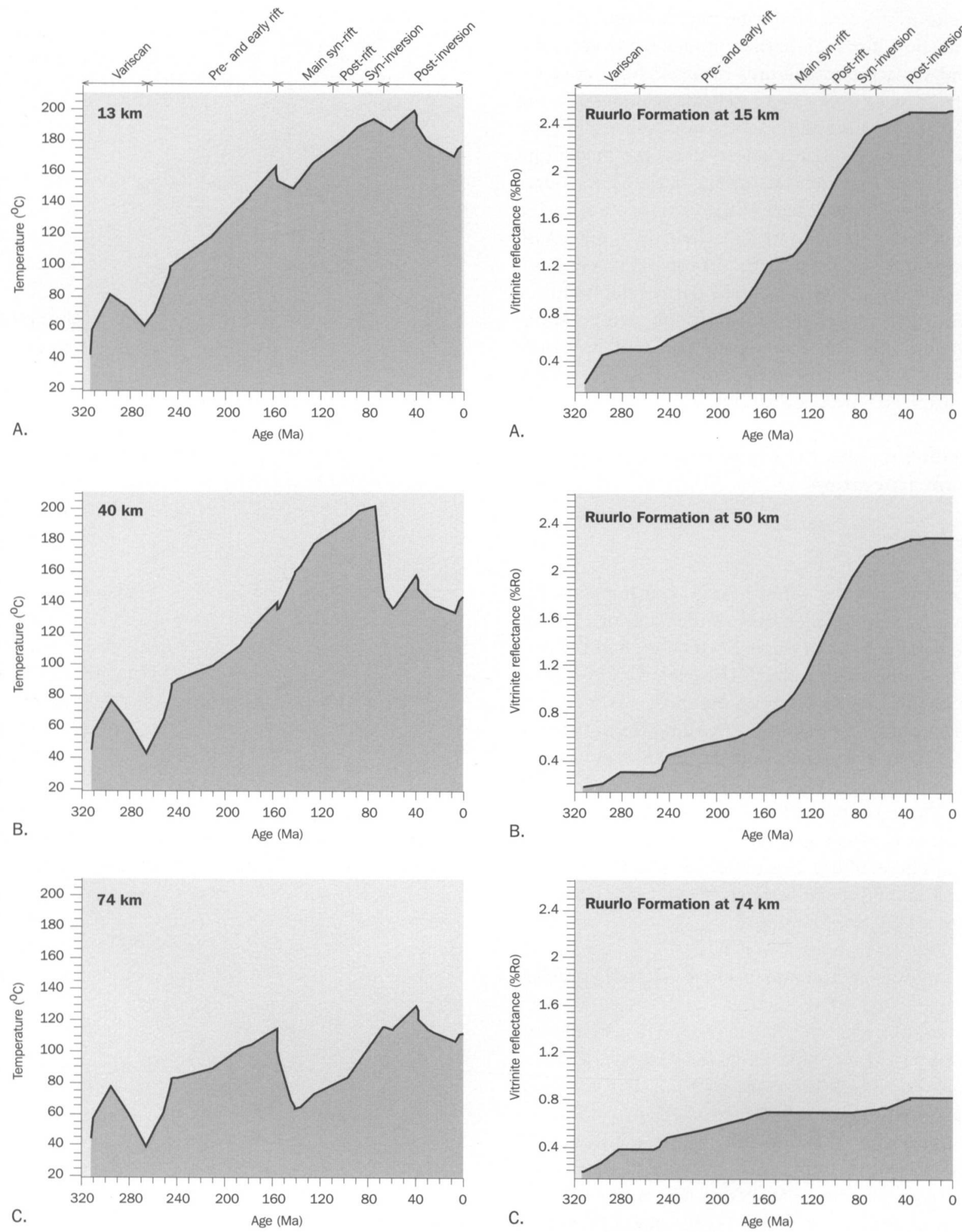

Fig. 7. Predicted temperature history and associated maturity history of the Limburg Group source rock in the southern (at 13-15 km), central (at 40-50 km) and northern (at $74 \mathrm{~km}$ ) part of the cross-section through the Broad Fourteens Basin.

while in the northern platform area, $\mathrm{CO}_{2}$ was not generated until syn-inversion times.

The modelling revealed that there was major generation of oil from the Posidonia Shale Formation in the central part of the basin during post-rift times prior to inversion (Figs 9 and 10). In the southern part of the cross-section, oil generation started during the Late Cretaceous and continued during the Early Tertiary post-inversion period. Little or no oil generation was predicted along the entire cross-section after the Eocene-Oligocene tectonic phase (Fig. 10). The pattern of the simulated history of oil generation from 

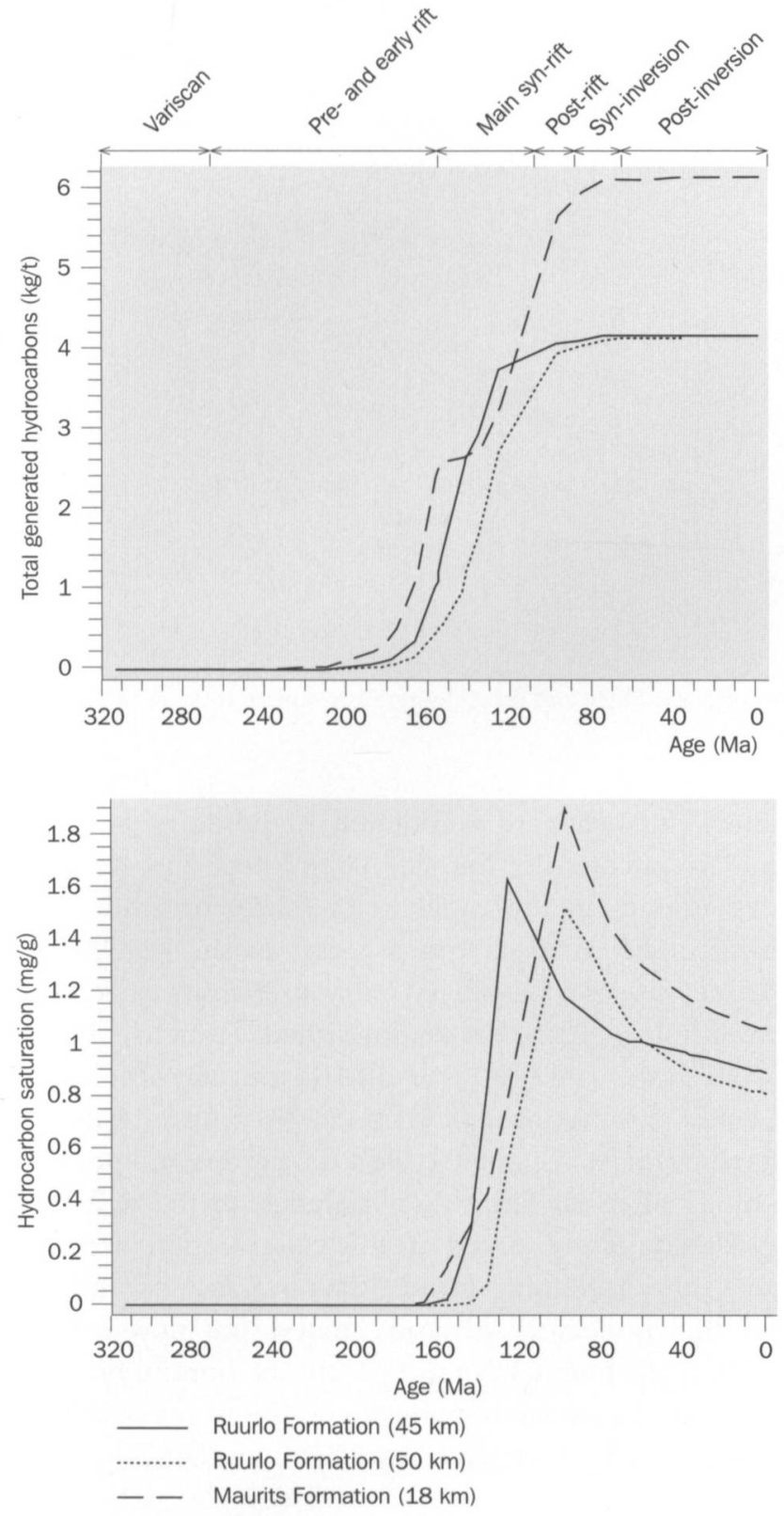

Fig. 8. Carboniferous gas system: predicted history of hydrocarbon generation and saturation in the Ruurlo Formation in the central part of the Broad Fourteens Basin (at $45-50 \mathrm{~km}$ along the crosssection) and in the Maurits Formation in the southern part of the basin (at $18 \mathrm{~km}$ along the cross-section).

the Aalburg Formation was the same pattern as the one for the Posidonia Shale Formation (Fig. 10), but the total amount of oil generated from the Aalburg Formation was smaller.

\section{Modelling results: history of petroleum expul- sion, migration and accumulation}

\section{Input data and boundary conditions}

The migration module simulates the history of petroleum expulsion from the source rocks and the subsequent secondary migration and accumulation of petroleum as a separate phase flow adopting a twophase Darcy equation. This two-phase Darcy equation includes buoyancy, pressure gradients and capillary pressure gradients as forces of influence on separate phase flow. It simulates the gas system and the oil system separately. The oil system simulations include the Posidonia Shale Formation and the Aalburg Formation simultaneously as the oil-prone source rocks. The parameters in the Darcy equation influence both the timing of petroleum expulsion from the source rock and the pattern of petroleum migration. Important input parameters for the expulsion and migration module are the fluid properties, magnitude of capillary pressures the rock permeabilities and the effective permeabilities of the rocks to the fluids (see Appendix). The fluid densities have been held constant during the modelling. The adopted densities of water,
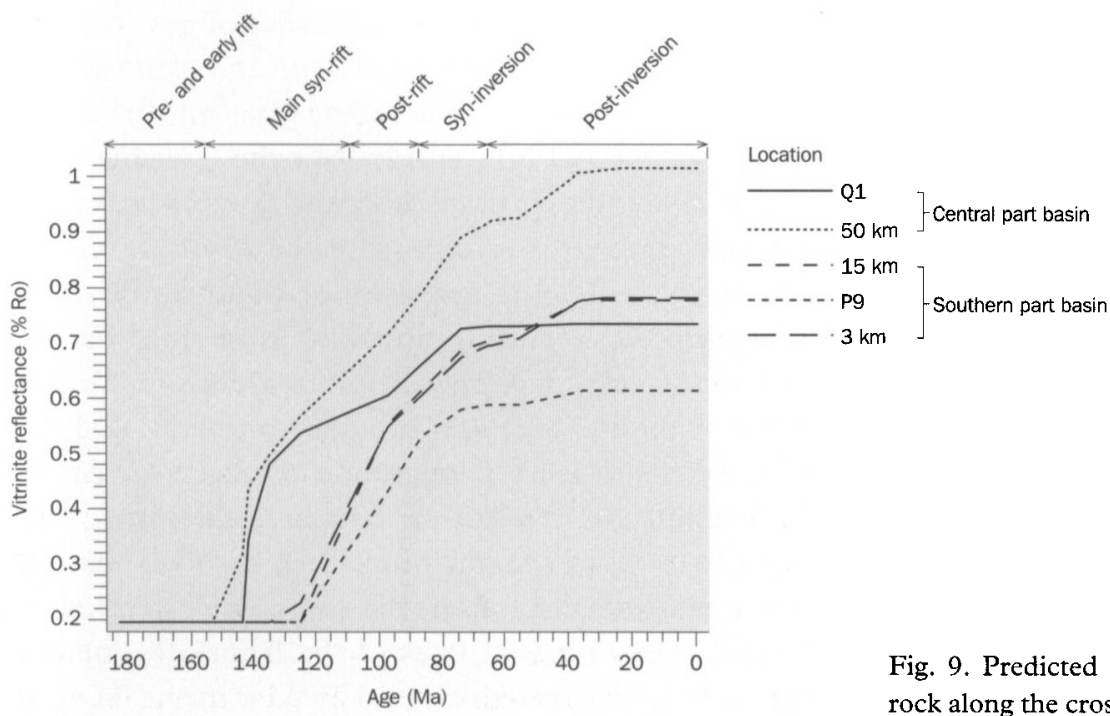

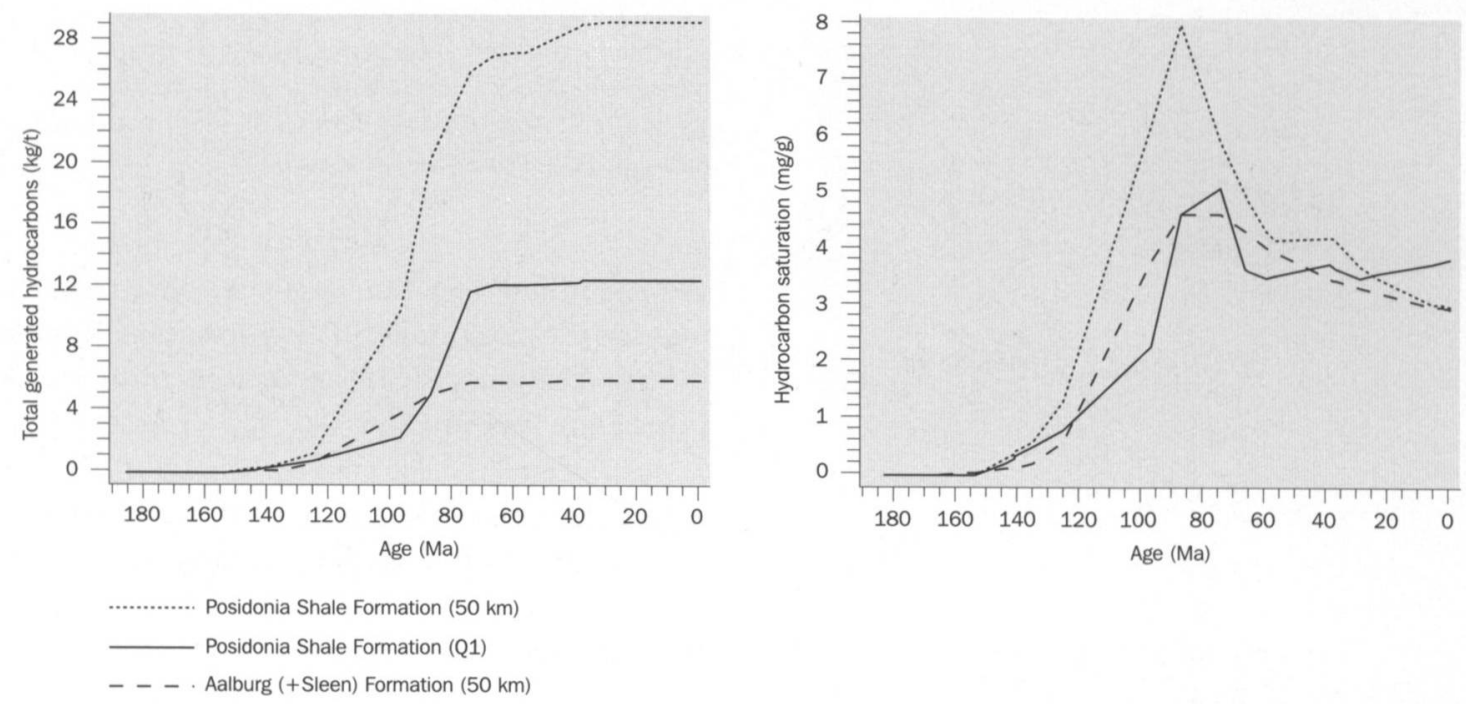

part of the Broad Fourteens Basin.

gas and oil are respectively $1030 \mathrm{~kg} / \mathrm{m}^{3}, 300 \mathrm{~kg} / \mathrm{m}^{3}$, and $500 \mathrm{~kg} / \mathrm{m}^{3}$. Default Temispack values have been used for the viscosities of water, oil and gas. Porosity and permeability Kozeny-Carman functions are critical inputs. Permeabilities are lithology dependent and anisotropic. We derived intrinsic permeabilities from the observed lithologies, and verified them against permeability data available for the main reservoir units. Anisotropies have been inferred from lithostratigraphic data (Van Adrichem Boogaert \& Kouwe, 1993-1997). The fault columns are defined to be of low permeability $\left(\mathrm{k}_{\mathrm{h}}=\mathrm{k}_{\mathrm{v}}=3 \times 10^{-5} \mathrm{mD}\right.$ at $10 \%$ porosity; capillary pressure $\mathrm{C}_{\mathrm{p}}=0.1 \mathrm{MPa}$ ) except during periods of tectonic activity (Late Jurassic rifting and Late Cretaceous inversion and - for faults in the P9 and Q1 area - also during Eocene-Oligocene uplift), when the permeabilities in the fault zone are allowed to increase to $\mathrm{k}_{\mathrm{h}}=3 \times 10^{-2} \mathrm{mD}$ and $\mathrm{k}_{\mathrm{v}}=3 \times 10^{-1} \mathrm{mD}$ (for $10 \%$ porosity; $\mathrm{C}_{\mathrm{p}}=0.1 \mathrm{MPa}$ ). The two-phase fluid flow modelling requires additional parameter values for two-phase fluid flow. The dependence of the relative permeabilities on petroleum saturation are given by relative permeability functions. The adopted relative permeability function for sand-and chalk-dominated lithologies, is defined by petroleum saturation end points of 0.05 and 0.98 and an exponent of 1.5 , giving the curvature of the function. For other lithologies the petroleum saturation end points are 0.1 and 0.98 . These relative permeability curves indicate that oil and gas will start to flow in sand-and chalk-dominated lithologies if petroleum saturation is above $5 \%$, and in other lithologies if saturation exceeds $10 \%$. Hence, the expulsion of gas from the Limburg Group source rocks will not start until gas saturation in the source rock exceeds $10 \%$. Capillary entry pressures are a function of lithology and are mainly affected by the size of the pore throats. The dependency of the capillary pressures on saturation has not been taken into account in the modelling. Three classes of capillary entry pressures, as related to lithology, can be distinguished (Burrus, 1997; Welte et al., 1997): $\mathrm{C}_{\mathrm{p}}=1-5 \mathrm{MPa}$ for tight lithologies (shales and evaporites); $\mathrm{C}_{\mathrm{p}}=0.1 \mathrm{MPa}$ for intermediate lithologies; $C_{p}=0.01 \mathrm{MPa}$ for porous and permeable lithologies. The values assigned to the different modelling layers, based on this classification, are given in the Appendix. Fluid flow boundary conditions for the modelling scenarios include no flow conditions at the lateral boundaries and the bottom boundary, and an upper boundary condition given by hydraulic head, as related to surface topography.

\section{Predicted expulsion, migration and accumulation of gas}

Model results indicate that expulsion of gas from the Limburg Group source rocks in the central and southern part of the cross-section started during the main syn-rift period. At $125 \mathrm{Ma}$ the gas migration system along the cross-section was dominated by this vertical upward expulsion from the Limburg Group source rocks. The overpressure gradients at this time were directed vertically upwards from the Limburg Group towards the Upper Rotliegend Group (Verweij \& Simmelink, 2002) and provided an additional driving force for upward migration of gas. As a consequence, the gas invaded the Upper Rotliegend Group as early as main syn-rift times. Fig. 8 shows that the expulsion rate of gas from the source rocks started to exceed the generation rates in the Ruurlo Formation (at $45 \mathrm{~km}$ ) at approximately $125 \mathrm{Ma}$, in the Maurits 
Formation (at $18 \mathrm{~km}$ ) and the Ruurlo Formation (at $50 \mathrm{~km}$ ) at approximately $100 \mathrm{Ma}$.

The expulsion of gas from the Limburg Group source rocks continued during post-rift times. During these times the secondary migration system in the southern part of the cross-section was characterised by bedding parallel updip migration through the Upper Rotliegend Group from 32 to $26 \mathrm{~km}$, subsequent vertically upwards cross-formational migration through Zechstein and Triassic Group units until the gas reached the reservoir type Triassic units (Detfurth and Solling Formations), where it accumulated in structural traps (for example in a trap located at 25 $\mathrm{km}$ along the cross-section). Further south at P9 and $18 \mathrm{~km}$, the secondary migration system was also dominated by vertical upward cross-formational migration through Zechstein and Lower Germanic Trias Group units, followed by the introduction of gas into the Detfurth and Solling reservoir units. At the end of the post-rift period predicted gas saturations were high in the Solling Formation at $16 \mathrm{~km}$. The Upper Triassic and Jurassic poorly permeable units did not halt the vertical upward migration of gas in the crestal structures in the southern part of the cross-section. Obviously, the gas that accumulated in the Solling Formation in the crestal areas provided enough buoyancy to overcome the capillary entry pressures in the overlying low permeable units. Model results indicate that the Zechstein Group in the southern part of the basin allowed the vertical escape of gas. In this southern part of the basin the Zechstein Group doesn't include evaporite deposits and is principally composed of clastic lithologies (53\% shale, $17 \%$ sandstone, $30 \%$ carbonates) with an assigned capillary pressure of 0.1 $\mathrm{MPa}$. The high capillary pressures of the Zechstein evaporites ( $5 \mathrm{MPa}$ ), in combination with their poor permeabilities and the magnitude of the groundwater overpressures during post-rift times, effectively seal the Upper Rotliegend Group in the central part of the basin north of P6. After expulsion of gas from the Limburg Group source rock the gas migrated updip through the Upper Rotliegend Group and accumulated in crestal structures, e.g at $50 \mathrm{~km}$.

After the Late Cretaceous inversion period the expulsion of gas from the Limburg Group source rock leveled out (Fig. 8). The changing geometries of the hydro-stratigraphic framework, in combination with the modelled increased permeabilities of the fault zones during the syn-inversion period were the major factors of influence on the secondary gas migration system. In the central part of the basin the secondary migration through the Upper Rotliegend Group was focussed from the deepest part of the Upper Rotliegend Group towards the faulted crestal high area at P6. It included remigration of gas from the former gas accumulation at $50 \mathrm{~km}$. After reaching the fault zone at P6 gas moved vertically upwards along the faults. At shallower levels part of the gas left the fault zone and invaded reservoir-type horizons and part of the gas escaped into the atmosphere. In the northern half of the central part of the basin, the gas migrated updip through the Upper Rotliegend Group towards the Q1 fault system.

South of the P6 area - between 16 and $28 \mathrm{~km}$ along the cross-section - updip migration of gas through the Slochteren and Solling Formations was also directed towards the faulted crestal high P6 area. Gas that had previously accumulated remigrated and some accumulated again in an updip trapping structure (for example in the Solling Formation at $28 \mathrm{~km}$ ).

Model results show that the syn-inversion topographyinduced groundwater flow system did not prevent vertical upward migration of gas through the P6 fault zone, nor the updip migration of gas in the Slochteren Formation and the Triassic sandstones (Verweij 2003).

Most of the gas in the basin was generated in the southern part of the basin. Here, the gas was distributed throughout the post-Carboniferous strata by bedding parallel and cross-formational migration of gas and by inversion-related remigration and escape to the atmosphere. As a consequence only a restricted number of gas fields were predicted to be present in the southern part of the basin at present-day (Fig. 11).

Increased gas saturations of $>90 \%$ are predicted in the Solling Formation in structural traps at approximately 20 and $28 \mathrm{~km}$ along the cross-section. The preserved saturation of gas in the Slochteren Formation in the P6 crestal area was calculated to be $18 \%$. At shallower levels in the P6 area some of the gas that escaped along the P6 fault zone during periods of tectonic activity, accumulated in Triassic reservoirs (Detfurth/Volpriehausen/Solling Formations) and in Delfland Subgroup sandstones. The model predicted increased gas saturations in these reservoir units at present-day. North of the P6 structural high, the vertical escape of the gas from the Slochteren Formation was effectively stopped during basin history by the continuous Zechstein seal rock. Much of pre-inversion gas accumulations remigrated towards the P6 area during the syn-inversion period. Since no favourable trapping structure was available in which the remigrating gas could accumulate, no significant present-day gas fields were predicted in the Slochteren Formation north of P6. In the Q1 fault zone the Zechstein seal was breached during the syninversion and Eocene-Oligocene periods of tectonic activity and associated modelled increase in fault permeability. This enabled some of the Slochteren gas to 

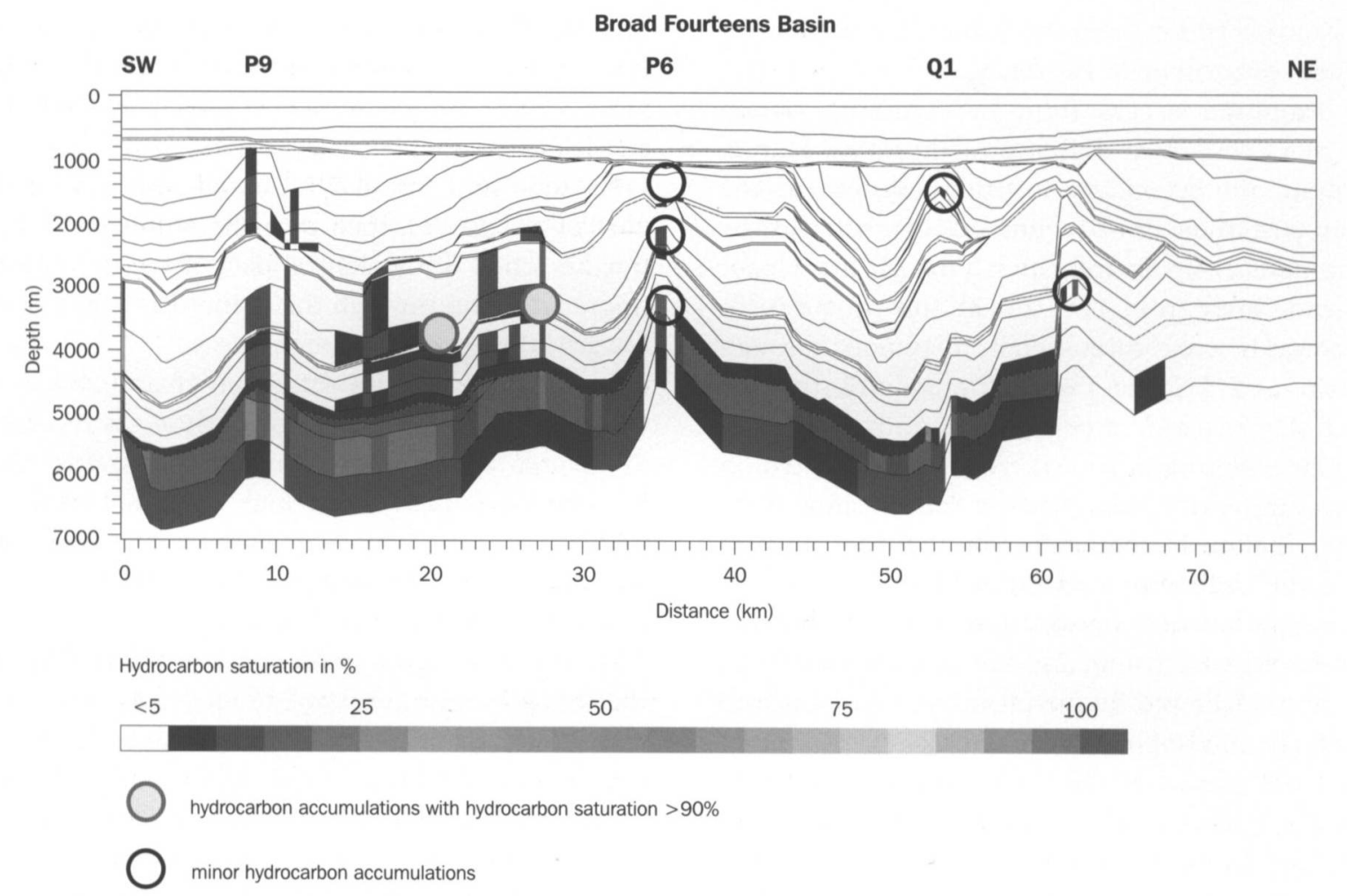

Scenario: time-dependent permeability faults; no Zechstein evaporite seal in southern part basin (22-30 km)

Fig. 11. Predicted present-day hydrocarbon saturation in the Carboniferous gas system.

escape vertically upward along the Q1 fault zone and infiltrate into the Vlieland Sandstone Formation at shallower depths. The modelling predicted a minor amount of gas trapped in this reservoir in the anticlinal structure at Q1 at present-day.

As the Zechstein Group in the central and northern part of the cross-section includes evaporite deposits it was modelled with lithology-based poor permeabilities and a high capillary entry pressure $(5 \mathrm{MPa})$. The modelling results clearly show that these characteristics of the Zechstein evaporites prohibited gas migration, an effect augmented by overpressure gradients counteracting cross-formational migration through the Zechstein. In contrast, the modelling results show that fine-grained clastic lithologies of poor permeabilities with capillary pressure of $\leqslant 1 \mathrm{MPa}$ may still allow cross-formational migration of gas. The uninterrupted presence of a Zechstein evaporite caprock effectively sealed the Slochteren Formation in the central part of the basin. Only, if this Zechstein evaporite seal is breached, e.g. by active fault zones (P6 and Q1 fault zones), did the model predict escape of gas through the caprock.

\section{Predicted expulsion, migration and accumulation of oil}

The model results predicted a negligible expulsion of oil from the Aalburg Formation during basin history. The conditions in the Aalburg Formation are unfavourable for drainage: in the model the organic matter was dispersed throughout the Aalburg Formation; in addition, the shale unit is thick (present-day thickness up to $896 \mathrm{~m}$ at $\mathrm{P9}$ ) and of poor porosity and permeability, and as a consequence could not permit an efficient primary migration and expulsion.

During basin history oil saturation in the Posidonia Shale Formation remained below $10 \%$ at relatively shallow depths in the southern part of the cross-section, not allowing oil to migrate through the source rock. Only the parts of the Posidonia Shale Formation buried more deeply in the southern part of the cross-section reached oil saturations that allowed expulsion of oil (e.g. at $3 \mathrm{~km}$ and $13 \mathrm{~km}$ ).

In the central - deepest - part of the pre-inversion basin (at $40 \mathrm{~km}$ ), expulsion of oil from the Posidonia Shale Formation started at approximately $125 \mathrm{Ma}$, i.e. during the latest part of the main syn-rift period. The expulsion rates in this part of the basin started to exceed generation rates in post-rift times (Fig. 10). The post-rift period is the main period of oil expulsion in the central part of the basin is, while in the southern part of the basin significant expulsion does not start until post-inversion times.

The oil migration system in the central part of the 
basin during post-rift times was characterised by: initial updip migration of oil through the anisotropic source rock, expulsion of oil from the source rock and subsequent cross-formational migration of oil in crestal structures, followed by the introduction of oil into the Middle Werkendam Member and - south of P6 also in the sand-dominated units in the Delfland Subgroup, and finally the updip migration of oils and their entrapment in these reservoir units.

Just prior to inversion, the main oil accumulations predicted by the model occurred in crestal structures in the Middle Werkendam Member at 26, 38, 47 and $53 \mathrm{~km}$ and in the sandy units of the Delfland Subgroup at $26 \mathrm{~km}$. Secondary accumulations are predicted in the Delfland Subgroup at P6.

The migration and remigration of oil during the syn-inversion period were strongly influenced by the changing geometry of the basin fill and the increased permeability of the active fault zones. Remigration was focussed towards the P6 and Q1 fault zone areas. The post-rift oil accumulations in the Middle Werkendam Member at 47 and $53 \mathrm{~km}$ were emptied and the southward and updip remigrating oils filled the Middle Werkendam Member in the crestal structure at $42 \mathrm{~km}$. During inversion, oil reached the Schieland Group sandstones by cross-formational flow at $45 \mathrm{~km}$ and subsequently migrated updip towards the P6 area. The previously accumulated oils in the Middle Werkendam Member at $38 \mathrm{~km}$ and in the Schieland Group sandstones at appoximately $26 \mathrm{~km}$ were preserved during inversion. Inversion-related increase in fault permeability permitted oil to remigrate from the Middle Werkendam Member into the Vlieland Sandstone Formation at Q1.

During inversion the oil accumulated in the

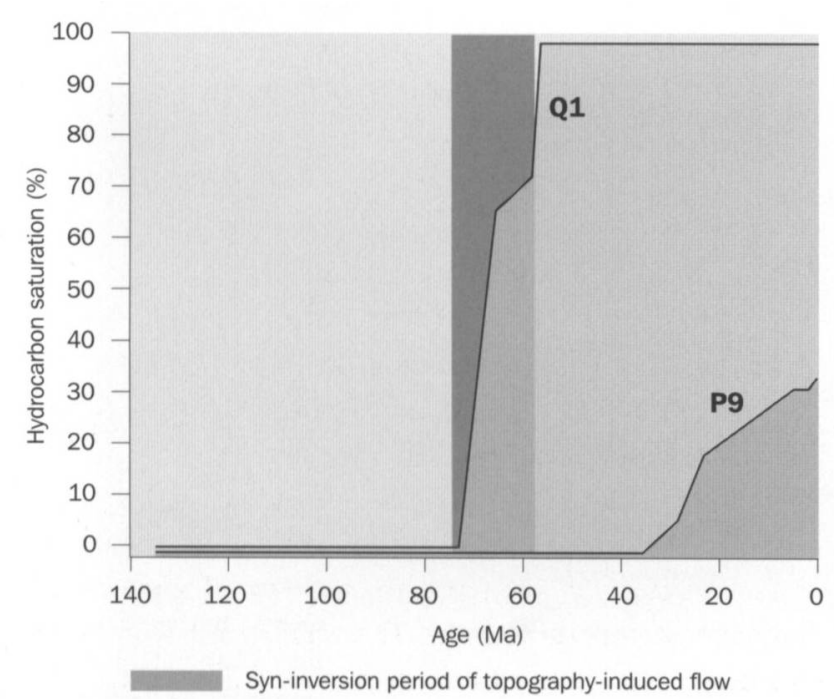

Fig. 12. Oil filling histories of the Lower Cretaceous reservoirs in the Q1 and P9 areas (From Verweij \& Simmelink, 2002).
Vlieland Sandstone Formation in the Q1 area was in the realm of the active regional topography-induced groundwater flow system (Verweij \& Simmelink, 2002; Verweij, 2003, Fig. 12).

In the area south of the P6 fault zone, remigration of oil through the Middle Werkendam Member and the Delfland Subgroup sandstones was principally updip. Oil accumulated in the modified crestal structure at approximately $26 \mathrm{~km}$. It was predicted that an oil-filled crestal structure was already present, pre-inversion, at approximately the same location. The oil migrating northward from $29 \mathrm{~km}$ towards the $\mathrm{P} 6$ fault zone escaped through the faults. In the southernmost part of the cross-section $(0-20 \mathrm{~km})$ no oil reached the Vlieland Sandstone Formation during the inversion period.

In the southernmost part of the cross-section the expulsion of oil from the Posidonia Shale Formation started to exceed the generation rate of oil in the source rock from the Eocene-Oligocene. The oil expelled from the Posidonia Shale Formation south of P9 migrated vertically upwards until it reached the Middle Werkendam Member and subsequently moved updip towards the P9 crestal area. In the basin north of the P9 structure, the expelled oil also reached the Middle Werkendam Member. However, the oil saturations in the Middle Werkendam Member north of P9 were too low to permit updip secondary migration of oil towards P9. The predicted oil saturation history of the Lower Cretaceous Vlieland Sandstone Formation in the crestal structure at P9 shows that the trap started to fill during the EoceneOligocene phase of tectonic activity (Fig. 12). In the model, the increased fault zone permeability allowed the faults to drain the oil from the Middle Werkendam Member.

The model reproduced the two known oil accumulations in the Vlieland Sandstone Formation, that is the oil accumulations in the crestal structures at Q1 and P9 (Figs $12 \&$ 13). Although the Q1 and P9 oil fields have been charged with oil from the same Posidonia Shale source rock, their chemical characteristics are predicted to be different. The Q1 reservoir was filled by remigrating oils, expelled during a prolonged time, from early mature to mature Posidonia shales. In addition the oils were exposed to syn-inversion topography-induced flow of groundwater that may have induced water washing and biodegradation of the oils. The accumulated oils in the P9 area were sourced from an early mature part of the Posidonia Shale Formation and were probably not affected by water washing and biodegradation because of post-inversion charging of the structure (Fig. 12). The predicted oil compositions are similar to known charac- 


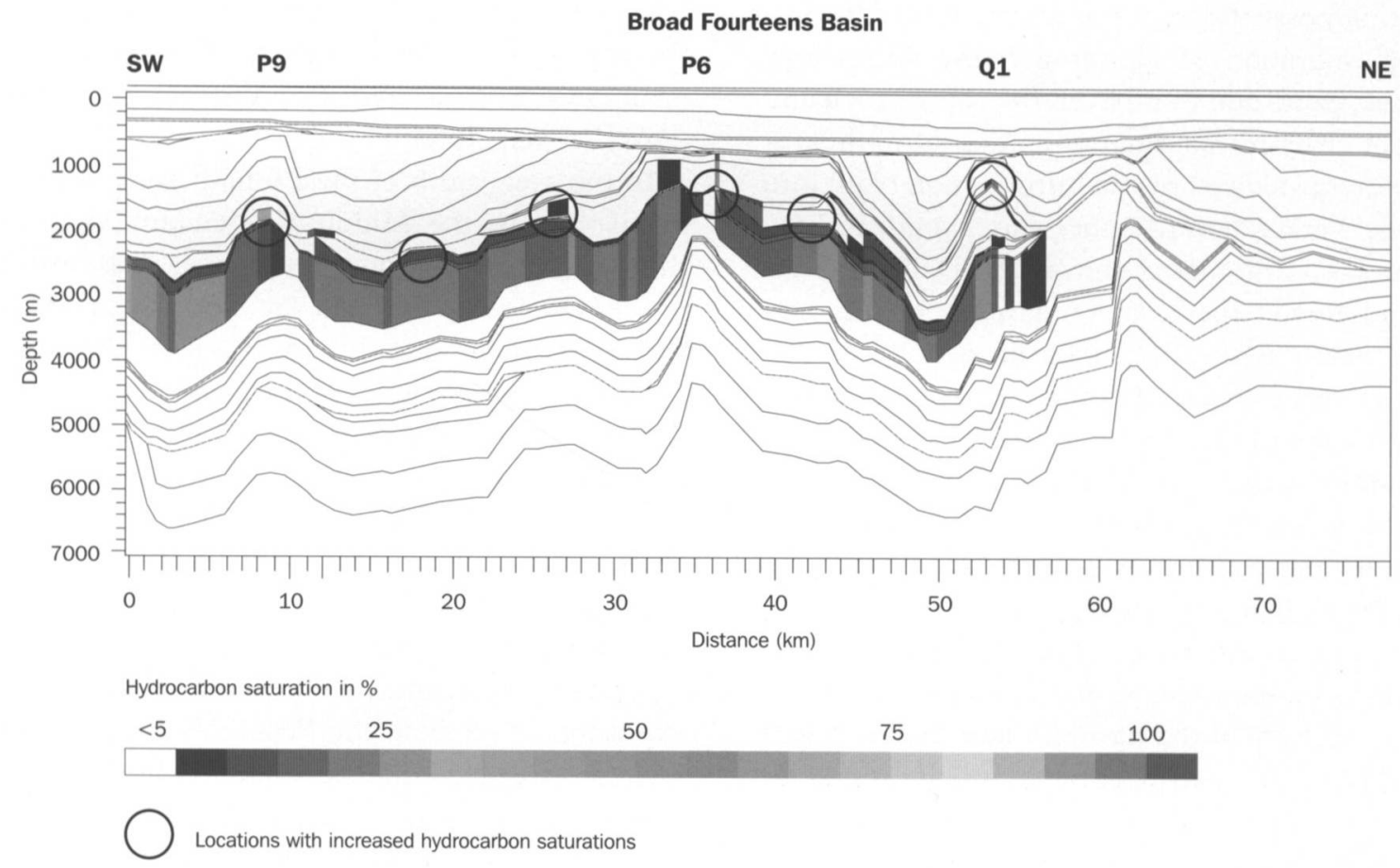

Fig. 13. Predicted hydrocarbon saturation in the Lower Jurassic oil system at present-day.

teristics of the producing oil fields.

The modelling predicted that oil saturations exceeding $80 \%$ would occur in the southern part of the cross-section in the Middle Werkendam Member at $18 \mathrm{~km}$ and $26.5 \mathrm{~km}$ and in the sandstones of the Delfland Subgroup at $26.5 \mathrm{~km}$, and in the central part of the cross-section in the Middle Werkendam Member at $42 \mathrm{~km}$. In addition, increased oil saturations were predicted in the sandstones of the Delfland Subgroup at the P6 crestal high (at 33-34 km and 36 $\mathrm{km}$ ) and in the Middle Werkendam Member just north of P6. The P6 area was the basin-wide recharge

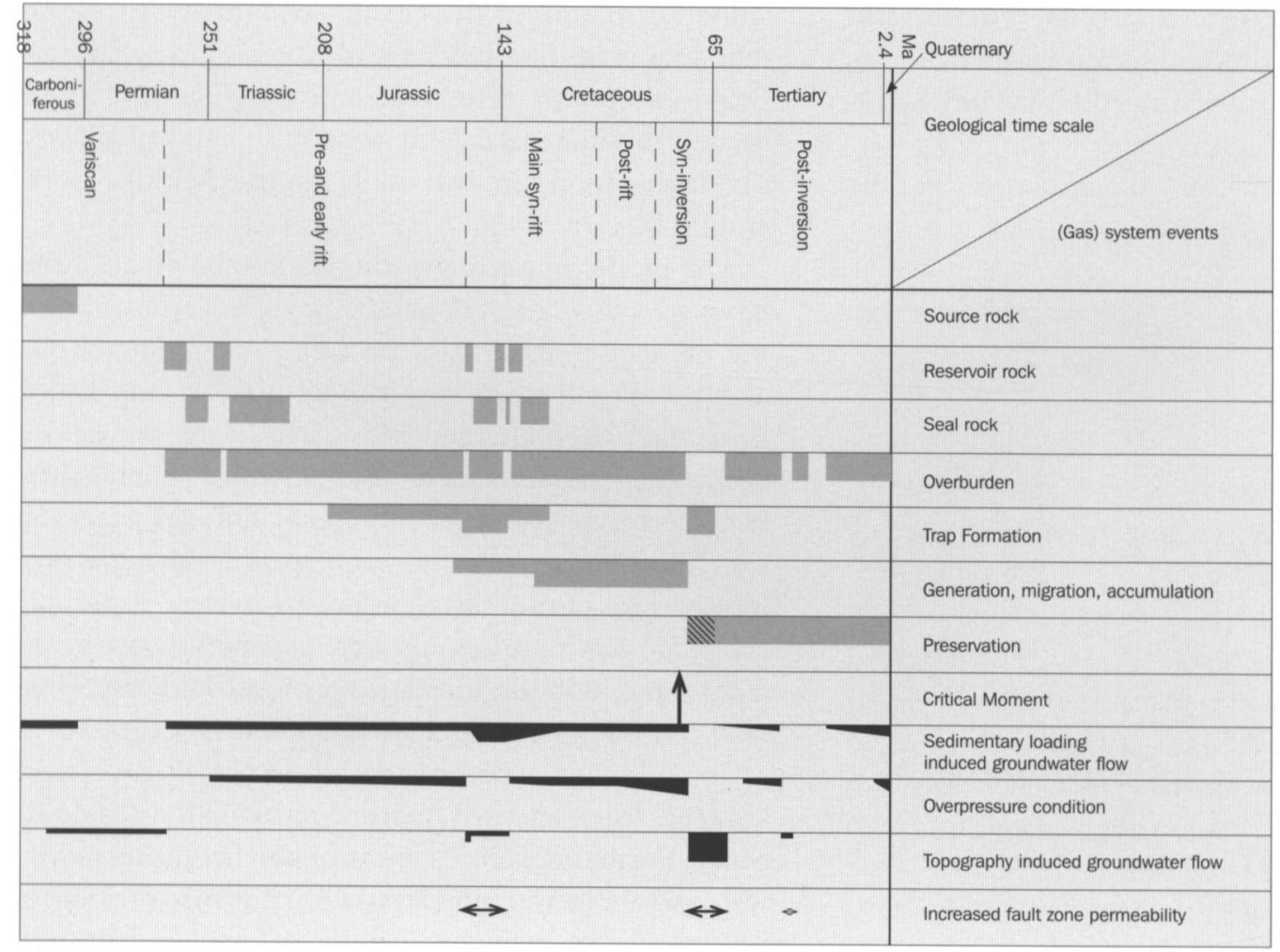

Remigration
Fig. 14. Events chart showing model-predicted timing of essential elements and processes of the Carboniferous gas system in the central part of the southern Broad Fourteens Basin. 


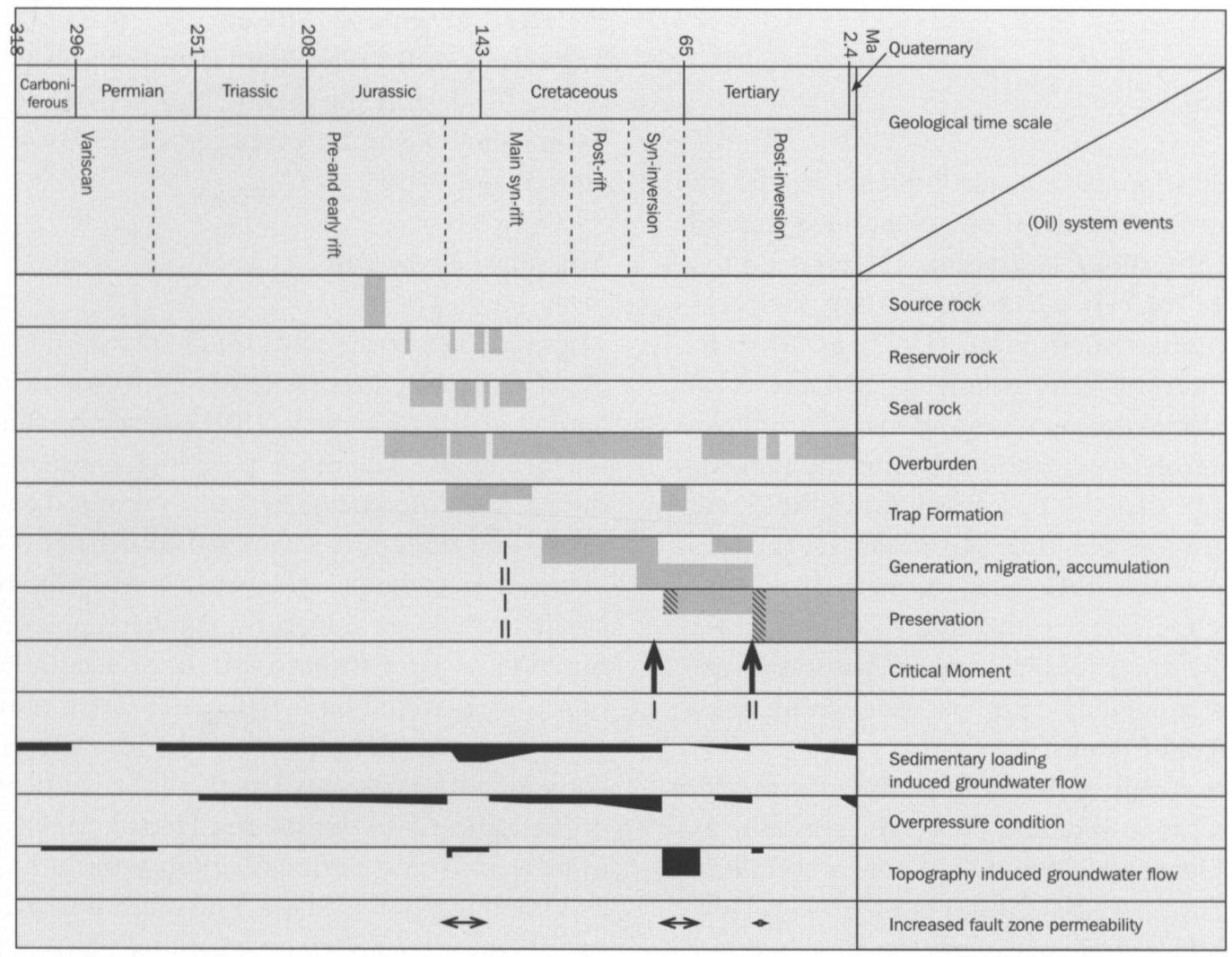

\footnotetext{
I Central basinal part of cross-section through Broad Fourteens Basin

II Southern part of cross-section through Broad Fourteens Basin

Remigration
}

Fig. 15. Events chart showing model-predicted timing of essential elements and processes of the Posidonia Shale oil system in the central part of the southern Broad Fourteens Basin.

area of the topography-induced groundwater flow system during syn-inversion times. Oils remigrating and trapped in the P6 area at that time were in the realm of active meteoric flow (Verweij \& Simmelink, 2002; Verweij, 2003), and as a consequence in a favourable position to be affected by water washing, and possibly biodegradation.

\section{Petroleum system events charts}

The gas and oil system events charts (Figs $14 \& 15$, respectively) summarise the time framework for petroleum generation, migration, accumulation and preservation in the basin as derived from the modelling study and previous data analysis. In comparison with the classical petroleum system events charts, as introduced by Magoon \& Dow (1994), Figs 14 \& 15 also incorporate the aspects of the hydrodynamic and hydrogeologic history of importance for evaluating the history of petroleum systems in the Basin.

A clear example of the influence of the groundwater flow system on the chemical characteristics of the petroleum system is the predicted concentrated topography-induced groundwater flow through the Vlieland Sandstone Formation during syn-inversion times. This phenomenon provided an explanation for the water washed and biodegraded nature of the Q1 oil reservoir charged in the Late Cretaceous (Fig. 12, Verweii \& Simmelink, 2002).

Modelling results also support the combined role of the groundwater system and the gas system in modifying the porosity and permeability conditions in the basin. For example, the predicted generation of $\mathrm{CO}_{2}$ in the Limburg Group source rocks during the early rifting period, and the contemporaneous sedimentary loading induced vertical upward expulsion of groundwater flow from the source rocks into the Slochteren Formation and overlying Zechstein Group is in accordance with conditions required to explain the observed formation of kaolin cement and leaching of Kfeldspar in the Slochteren Formation and calcite cements in the Z3 Carbonate Member of the Zechstein Group (Verweij \& Simmelink, 2002; Verweij, 2003). Verweij (2003) provides more detailed information on the interrelation of groundwater and petroleum systems during evolution of the Broad Fourteens Basin. 


\section{Discussion}

\section{Petroleum saturation}

Petroleum saturation has a major influence on the initiation of petroleum migration. Suggested magnitudes of bulk threshold saturations for carrier rocks range between 1\% (Hirsch \& Thompson, 1995), 3$5 \%$ for thick units (Mann et al., 1997) to $20 \%$ for thin units of several tens of meters (Mann et al. 1997). These breakthrough saturations also indicate the residual petroleum saturation, that is the percentage of petroleum that will be left behind in the carrier rock after migration. Residual saturations of the total available pore space have been estimated at 1-3\% (Mackenzie \& Quickley, 1988) and 5\% (England et al., 1987). The threshold petroleum saturation assumed in the modelling $(5 \%)$ is well within these published ranges of values.

The saturation values that control initial expulsion from source rocks in separate phase are generally assumed to be higher than those used for initial migration through carrier rocks (Mann et al. 1997). However, when modelling the petroleum systems in different basins Burrus (1997) used threshold saturations of only $2 \%$. In addition, Mann et al. (1997) consider threshold saturations of 2-5\% typical for modelling purposes if source rock cells are in the order of several tens of metres to $500 \mathrm{~m}$ in size. A single $10 \%$ threshold saturation for both the thin oil-prone Posidonia Shale Formation and the thick gas-prone Limburg Group source rocks was used in the modelling of the Broad Fourteens Basin. Source rocks with lower assigned threshold saturations would have started to expell their hydrocarbons earlier during basin history. In the modelling of the Broad Fourteens basin, kerogen was assumed to be distributed throughout the source rock. In the actual Limburg Group source rock, however, the kerogen is concentrated in distinct organicrich coal layers. A value of $10 \%$ for petroleum threshold saturations - as assumed in the model - can probably be considered as a maximum saturation at which petroleum starts to migrate in the source rocks. Given these considerations, it is unlikely that the petroleum expulsion from the source rocks in the Broad Fourteens Basin probably started later than the times the model predicted.

\section{Temperature and maturation}

The modelling showed a strong dependence of temperature and maturation history on burial during most of the geological history of the Broad Fourteens Basin. This dependence can probably also explain the relatively minor differences between the modelling results of the West Netherlands Basin (Van Balen et al., 2000) and this study. In a general sense, both basins show a similar evolution of hydrocarbon generation.

\section{Migration of petroleum}

Migration of petroleum through a basin fill is a multiphase fluid flow process (e.g. Schowalter, 1979; England et al.,1987; Verweij, 1993) driven by fluid potential gradients. The fluid potential gradients are induced by differences in excess groundwater pressures, buoyancy forces (related to density differences between petroleum and water), and differences in capillary pressures. In turn, capillary pressures are a function of pore throat radii, interfacial tension and pore throat wettability. The actual migration rates of petroleum, as described by the multiphase Darcy equation, are controlled by the effective permeability of the basin fill to petroleum. Hence, the distribution of pore sizes and permeability in a basin highly control the migration process. The migration pathways of petroleum are largely controlled by units of relatively high porosity and permeability, such as permeable fault and fracture zones, sand dominated lithostratigraphic units, and their structural dip or geometry. This is illustrated by the results of the $2 \mathrm{D}$ modelling of the petroleum system in the Broad Fourteens Basin. The geometry of these carrier-bed units and fault zones controlling the evolution of the migration pathways, remigration and accumulation has changed dramatically during the evolution of the basin. The basin is laterally constrained in the modelling. In addition, the modelling does not allow actual fault deformation. As a consequence, the reconstructions of paleogeometries are not structurally correct. However, the modelled cross-section was chosen perpendicular to the strike of the basin and basin boundary fault directions and it crosses the major depocentre of the combined Triassic to Lower Cretaceous deposits as well as the area of maximum uplift and erosion during syn-inversion times. In this way it captures the principal dip directions of the stratigraphic units and the major variations in dip directions of direct influence on petroleum migration pathways. The $2 \mathrm{D}$ basin modelling thus allows capturing the essence of the petroleum migration system. Although most buoyancydriven updip migration is in the direction of largest dip (that is along the cross-section), additional outof-plane migration of oil and gas is likely to have occurred during basin history. Today the maximum depth of the basin (indicated by the depth map of the top Carboniferous, i.e. Heybroek \& Van Wijhe 1987) 
extends from block Q1, towards blocks P3 and F18. The geometry of the top Carboniferous suggests that updip migration towards the cross-section cannot be excluded (e.g. from block F18 towards L16, and from block P3 towards Q1). It is recognised that actual charging of a structure as well as the integrity of a petroleum-filled structure at any time during basin history should ideally be evaluated in 3D.

In order to fill the known oil fields in the Vlieland Sandstone Formation in the Q1 and P9 areas with oil generated from the Posidonia Shale Formation, the oil somehow had to pass through the shale-dominated Werkendam Formation and Delfland Subgroup. The interpreted seismic data and lithostratigraphic well data available to this study did not provide detailed information on the occurrence, distribution and horizontal and vertical continuity of sand-dominated permeable facies within the Werkendam Formation and the Delfland Subgroup. Therefore, regional information was used instead to reconstruct the lithostratigraphy and hydrostratigraphy between wells. In the model lateral continuity of permeable sandy facies was assumed but no vertical connectivity between these facies. As a consequence the lithostratigraphic build-up adopted in the oil migration module, does not provide a potential cross-formational pathway for oil through the Delfland Subgroup. This is illustrated by the modelling results. The predicted Posidonia Shale-Vlieland Sandstone oil system (Q1) is dominated by focussed updip flow through the Middle Werkendam Member and subsequent vertical upward flow through the fault zone. The shales of the Upper Werkendam Member and the Delfland Subgroup do not allow widespread cross-formational flow. It is clear that more detailed information is required on the lithostratigraphic build-up especially of the Delfland Subgroup, in order to evaluate more confidently its actual role in oil history.

\section{Dynamic permeability of fault zones}

Given the tectonic activity during basin history and the indicators of permeability alterations and paleofluid flow through fracture and faultzones (Verweij, 2003), there is no doubt that dynamic fault and fracture permeability played a role in fluid migration during the evolution of the Broad Fourteens basin. The introduction of the dynamic permeability of the three fault zones in the modelled cross-section should be considered as an initial modelling scenario to take such dynamic permeabilities into account in fluid migration in the basin. The real magnitude of changes in permeability, storativity, capillary pressures, the duration of the changed properties and the volumes of flu- ids involved are unknown.

The model results revealed the influence of the dynamic permeability of the three fault zones on the secondary migration and remigration of both oil and gas. The interpreted seismic section (Fig. 2) shows more widespread faults in the Broad Fourteens Basin. These additional fault zones may also have played a role in the history of petroleum systems in the basin, for example, in the filling and preservation history of the predicted oil accumulations in the Middle Werkendam Member in the fault bounded crestal structures at 26.5 and $42 \mathrm{~km}$. These structures were filled prior to and during inversion. To be able to reliably evaluate the fault activity and related variations in permeability on the petroleum system, requires the dating and timing of fault movement and the reconstruction of phases of paleo groundwater flow.

\section{Conclusions}

The modelling demonstrated that large differences in the burial histories of the gas-prone Limburg Group and oil-prone Jurassic source rocks along the crosssection result in very different temperature and maturation histories for the source rocks depending on their structural position. In the central and southern part of the cross-section most gas was generated from the Limburg Group prior to inversion. In the northern platform area, a first phase of gas generation was initiated in the Early Tertiary. The modelling revealed that there was major generation of oil from the Posidonia Shale Formation in the central part of the basin during post rift times prior to inversion. The Early Tertiary was an important phase of oil generation in the southern part of the cross-section. Based on the modelling results, it seems likely that today there is no to only minor generation of gas from the Limburg Group source rocks and no to only minor generation of oil from the Posidonia Shale Formation along the cross-section.

The $2 \mathrm{D}$ basin modelling identified the following main characteristics of the gas and oil migration systems in the Broad Fourteens Basin:

\section{Gas system}

Expulsion of gas from the Limburg Group source rocks in the central and southern part of the crosssection started during the main syn-rift period. Peak expulsion of gas occurred in Cretaceous pre-inversion times. Gas expulsion leveled off since the Late Cretaceous inversion period.

The spatial variation in lithology and associated sealing property of the Zechstein Group resulted in 
different gas migration patterns along the cross-section. In the area south of the P6 structural high, where the clastic Zechstein Group is non-sealing, gas was distributed throughout the post-Carboniferous section by bedding parallel migration through sanddominated units and by cross-formational migration. North of the P6 area the sealing evaporite deposits of the Zechstein Group prevented vertical escape of gas from the Slochteren Formation. The migration system was dominated by updip flow through the Slochteren Formation. Breaching of the Zechstein seal by the P6 and Q1 fault zones allowed vertical upward escape of gas, especially during the syn-inversion and Pyrenean periods of tectonic activity.

Major pre-inversion gas accumulations were predicted in the Slochteren Formation at $50 \mathrm{~km}$ along the cross-section and in the Triassic sandstone-dominated units at 16 and $25 \mathrm{~km}$. The accumulation at 50 $\mathrm{km}$ was emptied during inversion and the remigrating gas escaped through the P6 fault zone. Inversion-induced remigration of gas in the Triassic reservoirs in the southern part of the basin was trapped again updip in the Triassic reservoirs, e.g. at $28 \mathrm{~km}$. The modelling predicted present-day increased saturations of gas in the Triassic sandstone-dominated units at 20 and $28 \mathrm{~km}$. No major gas accumulations were predicted in the Slochteren Formation. Gas migrating through the fault zones in the P6 and Q1 areas during periods of tectonic activity was in part introduced into post-Permian reservoirs, leading to increased present-day saturations of gas in especially the Triassic reservoirs.

\section{Oil system}

Total expulsion of oil from the Aalburg Formations was negligible. The expulsion of oil from the Posidonia Shale Formation was initiated in the central part of the basin during the latest stage of the main syn-rift period. The post-rift period was the main period of oil expulsion in the central part of the basin; in the southern part significant expulsion did not start until post-inversion times. Inversion induced widespread remigration of oil: remigrating oil charged the Middle Werkendam Member at $42 \mathrm{~km}$ and the Vlieland Sanstone Formation in the $\mathrm{Q} 1$ area; oil accumulations in the Middle Werkendam Member in structures at 38 and $47 \mathrm{~km}$ survived inversion. Charging of the Vlieland Sandstone Formation in the crestal structure at $\mathrm{P} 9$ started in the Early Tertiary.

The modelling reproduced the known oil accumulations in the Vlieland Sandstone Formation sealed by the Vlieland Shale Formation in the Q1 and the P9 crestal structures. The modelling predicted pre- sent-day oil saturations exceeding $80 \%$ in the Middle Werkendam Member at $18 \mathrm{~km}, 26.5 \mathrm{~km}$ and 42 $\mathrm{km}$ and in the sandstones of the Delfland Subgroup at $26.5 \mathrm{~km}$. In addition it predicted increased saturations in the sandstones of the Delfland Subgroup at the P6 crestal high (at 33-34 km and $36 \mathrm{~km}$ ) and in the Middle Werkendam Member just north of P6. An additional modelling result is the process-based understanding of the different geochemical compositions of the accumulated oils in the P9 and Q1 area.

\section{Acknowledgements}

The authors thank Mark Geluk and Nora Witmans for their contribution to the research project, and Roel van der Kraan and André Koers for their help in preparing the illustrations. We also thank Ewan Campbell and an anonymous reviewer for their thoughtful and constructive review of the manuscript.

\section{References}

Burgers, W.F.J. \& Mulder, G.G., 1991. Aspects of the Late Jurassic and Cretaceous history of the Netherlands. Geologie en Mijnbouw 70: 347-354.

Burrus, J., 1997. Contribution à l'étude du fonctionnement des systèmes pétroliers: apport d'une modélisation bi-dimensionnelle. Thèse. École des Mines de Paris. Centre d'Informatique Géologique, Paris, France.

Cornford, C., 1998. Source rocks and hydrocarbons of the North Sea. In: Glennie, K.W. (ed.). Petroleum geology of the North Sea area. Basic concepts and recent advances. Fourth edition. Blackwell Science Ltd. (Oxford): 376-462.

Crépieux, N., Sacleux, M. \& Mathis, B., 1998. Influence of the pressure on the petroleum system. Example from Triassic in the Netherlands Central Graben. In: Proceedings Workshop, Pau, April 1998. 'Overpressures in petroleum exploration'. Bulletin Centre Rech. Elf Explor. Prod. Mémoir 22: 123-131.

De Jong, M.G.G. \& Laker, N., 1992. Reservoir modelling of the Vlieland Sandstone of the Kotter Field (Block K18b), offshore, The Netherlands. Geologie en Mijnbouw 71: 173-188.

Dronkers, A.J. \& Mrozek, F.J., 1991. Inverted basins of The Netherlands. First Break 9: 409-425.

England, W.A., Mackenzie, A.S., Mann, D.M. \& Quigley, T.M., 1987. The movement and entrapment of petroleum fluids in the surface. Journal of the Geological Society, London 144: 327-347.

Frikken, H.W., 1996. CBIL logs: vital for evaluating disappointing well and reservoir performance, K15-FG field, central offshore Netherlands. In: Rondeel, H.E, Batjes, D.A.J. \& Nieuwenhuis, W.H. (eds.). Geology of oil and gas under the Netherlands. Kluwer Academic Publishers (Dordrecht, the Netherlands): 103-114.

Gauthier, B.D.M., Franssen, R.C.W.M. \& Drei, S. 2000 . Fracture networks in Rotliegend gas reservoirs of the reservoirs of the Dutch offshore: implications for reservoir behaviour. Geologie en Mijnbouw/Netherlands Journal of Geosciences 79 (1): 45-57.

Glennie, K.W. (ed.) 1998. Petroleum geology of the North Sea area. Basic concepts and recent advances. Fourth edition. Blackwell Science Ltd. (Oxford): $636 \mathrm{pp}$. 
Goh, L.S. 1996. The Logger oil Field (Netherlands offshore): reservoir architecture and heterogeneity. In: Rondeel, H.E., Batjes, D.A.J. \& Nieuwenhuijs, W.H. (eds), 1996. Geology of gas and oil under the Netherlands. Kluwer Academic Publishers, Dordrecht, the Netherlands: 255-263.

Hastings, A., Murphy, P. \& Stewart, L., 1991. A multi-disciplinary approach to reservoir characterization: Helm field, Dutch North Sea. In: Spencer, A.M. (ed.). Generation, accumulation and production of Europe's hydrocarbons. Special Publication of the European Association of Petroleum Geoscientists No. 1, Oxford University Press (Oxford): 193-202.

Heybroek, P. \& Van Wijhe, D.H. 1987. Structural interpretation of the subsurface since 1956. In: Visser, W.A., Zonnelveld, J.I.S. \& Van Loon, A.J. Seventy-five years of geology and mining in The Netherlands. Royal Geological and Mining Society of The Netherlands: 259-268.

Hirsch, L.M. \& Thompson, A.H., 1995. Minimum saturations and buoyancy in secondary migration. AAPG Bulletin 79: 696710 .

Knaap, W.A. \& Coenen, M.J., 1987. Exploration for oil and natural gas. In: Visser, W.A., Zonneveld, J.I.S. \& A.J. van Loon (eds) 1987. Seventy-five years of geology and mining in The Netherlands. Royal Geological and Mining Society of the Netherlands: 207-230.

Lee, M., Aronson, J.L. \& Savin, S.M., 1989. Timing and conditions of Permian Rotliegende sandstone diagenesis, Southern North Sea: K/Ar and oxygen isotopic data. AAPG Bulletin 73: 195215 .

Mackenzie, A.S. \& Quigley, T.M., 1988. Principles of geochemical prospect appraisal. AAPG Bulletin 72: 399-415.

Magoon, L.B. \& Dow, W.G., 1994. The Petroleum system from source to trap. AAPG Memoir 60:655 pp.

Mann, U., Hantschel, T., Schaefer, R.G., Krooss, B., Leythaeuser, D., Littke, R. \& Sachsenhofer, R.F., 1997. Petroleum migration: mechanisms, pathways, efficiencies and numerical simulations. In: Welte, D.H, Horsfield, B. \& Baker, D.R. (eds). Petroleum and Basin evolution. Insights from petroleum geochemistry, geology and basin modeling. Springer-Verlag (Berlin, Heidelberg, New York): 403-520.

Nalpas, T., Le Douaran, S., Brun, J.-P., Unternehr, P. \& Richert, J.P., 1995. Inversion of the Broad Fourteens Basin (offshore Netherlands), a small-scale model investigation. Sedimentary Geology 95: 237-250.

Oele, J.A., Hol, A.C.P.J. \& Tiemens, J., 1981. Some Rotliegend gas fields of the K and L Blocks, Netherlands Offshore (1968-1978) - A case history. In: Illing, L.V. \& Hobson, G.D. (eds). Petroleum geology of the continental shelf of north-west Europe. Heyden and Son Ltd/The Institute of Petroleum, London: 289-300.

Quirk, D.G. \& Aitken, J.F., 1997. The structure of the Westphalian in the northern part of the southern North Sea. In: Ziegler, K., Turner, P. \& Daines, S.R. (eds). Petroleum geology of the Southern North Sea. Future potential. Geological Society Special Publication 123: 143-152.

Roelofsen, J.W. \& De Boer, W.D., 1991. Geology of the Lower Cretaceous $Q / 1$ oil-fields, Broad Fourteens Basin, The Netherlands. In: Spencer, A.M. (ed.). Generation, accumulation and production of Europe's hydrocarbons. Special Publication of the European Association of Petroleum Geoscientists 1. Oxford University Press (Oxford): 203-216.

Roos, B.M. \& Smits, B.J., 1983. Rotliegend and Main Buntsandstein gas fields in block K/13 - a case history. Geologie en Mijnbouw 62: 75-82.

RRI - Robertson Research International, 1984. The Dutch North
Sea area: the stratigraphy and petroleum geochemistry of the Jurassic to Tertiary sediments.

RRI - Robertson Research International, 1985. The Permian, Triassic and Carboniferous reservoirs of the Dutch North Sea. A petroleum geology and engineering evaluation Volume 3.

RRI-Robertson Research International, 1988. Netherlands North Sea study: an integrated analytical and evaluation study incorporating petroleum geology, geophysics and reservoir engineering.

RRI-Robertson Research International, 1990. The Netherlands North Sea Well updates.

Schowalter, T.T., 1979. Mechanics of secondary hydrocarbon migration and entrapment. AAPG Bulletin 63: 723-760.

Simmelink, H.J. \& Verweij, J.M., 2000. Basin modelling of the Broad Fourteens Basin. Explanation of modelling steps, sensitivity analysis and results. Netherlands Institute of Applied Geoscience TNO - National Geological Survey, TNO-report NITG 00-36-A.

Ungerer, P., Burrus, J., Doligez, B., Chénet, \& Bessis, F., 1990. Basin evaluation by integrated two-dimensional modeling of heat transfer, fluid flow, hydrocarbon generation and migration. AAPG Bulletin 74: 309-335.

Van Adrichem Boogaert, H.A. \& Kouwe,W.F.P., 1993-1997. Stratigraphic nomenclature of the Netherlands, revision and update by RGD and NOGEPA. Mededelingen Rijks Geologische Dienst nr 50 .

Van Balen, R.T., Van Bergen, F., De Leeuw, C., Pagnier, H., Simmelink, H. Van Wees, J.D., \& Verweij, J.M., 2000. Modelling the hydrocarbon generation and migration in the West Netherlands Basin, the Netherlands. Geologie en Mijnbouw/Netherlands Joural of Geosciences 79: 29-44.

Van der Poel, A.B., 1989. A case study on the hydrocarbon geology of Upper Permian (Zechstein-3) carbonates in licence P6, the Netherlands' offshore. Geologie en Mijnbouw 68: 285-296.

Van Wiihe, D.H., 1987. The structural evolution of the Broad Fourteens Basin. In: Brooks, J. \& Glennie, K. (eds). Petroleum Geology of North West Europe. Graham and Trotman: 315-323.

Van Wijhe, D.H., Lutz, M. \& Kaasschieter, J.P.H., 1980. The Rotliegend in the Netherlands and its gas accumulations. Geologie en Mijnbouw 59: 3-24.

Verweij, J.M., 1993. Hydrocarbon migration systems analysis. Developments in Petroleum Science 35, Elsevier (Amsterdam): 276 pp.

Verweij, J.M., 2003. Fluid flow systems analysis on geological time scales in onshore and offshore Netherlands; with special reference to the Broad Fourteens Basin (in press).

Verweij, J.M. \& Simmelink, H.J., 2002. Geodynamic and hydrodynamic evolution of the Broad Fourteens Basin (The Netherlands) in relation to its petroleum systems. Marine and Petroleum Geology 19: 339-359.

Verweij, J.M., Simmelink, H.J., David, P., Van Balen, R.T., Van Bergen, F. \& Van Wees, J.D.A.M., 2000. Geodynamic and hydrodynamic evolution of the Broad Fourteens Basin and the development of its petroleum systems: an integrated 2D basin modelling approach. Journal of Geochemical Exploration 69-70: 635639.

Welte, D.H, Horsfield, B. \& Baker, D.R. (eds), 1997. Petroleum and Basin evolution. Insights from petroleum geochemistry, geology and basin modeling. Springer-Verlag (Berlin, Heidelberg, New York): 535 pp.

Wong, Th.E., Parker, N. \& Horst, P., 2001. Tertiary sedimentary development of the Broad Fourteens area, the Netherlands. Netherlands Journal of Geosciences/Geologie en Mijnbouw 80: 85-94. 


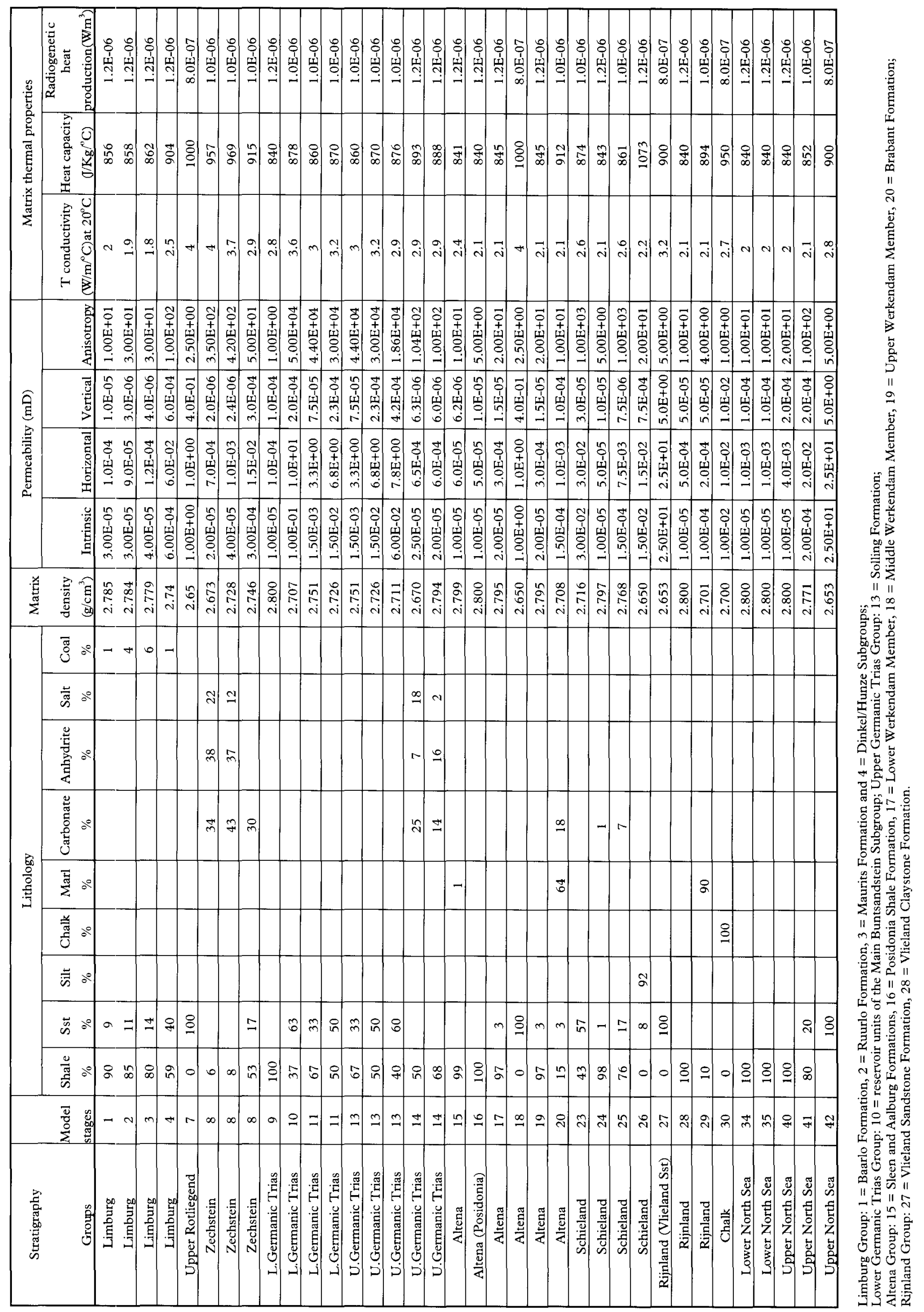

